\title{
LIEUTENANT GENERAL PATTON'S SEVENTH ARMY IN SICILY 1943: THE MATURATION OF AN AMERICAN OPERATIONAL ARTIST
}

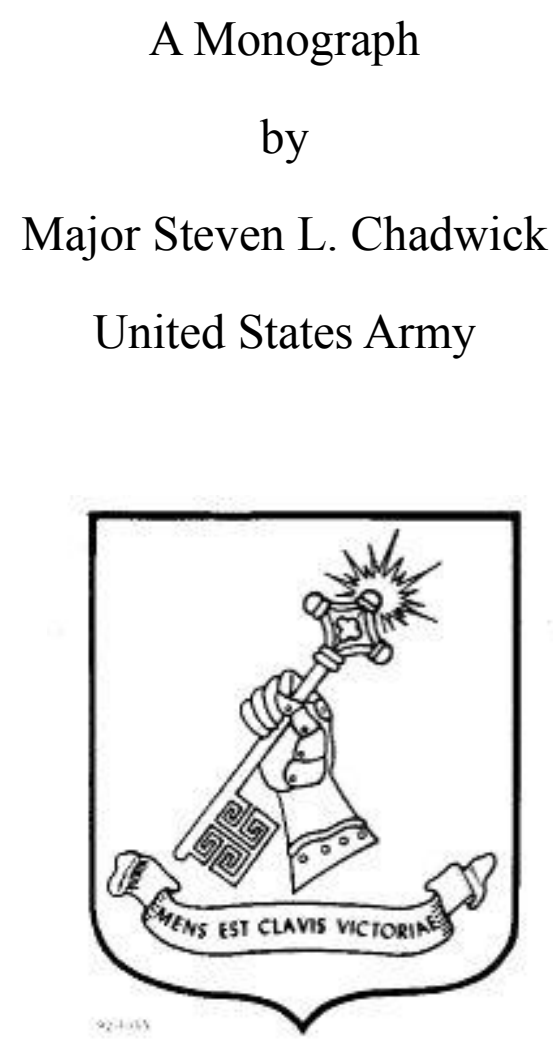

School of Advanced Military Studies

United States Army Command and General Staff College

Fort Leavenworth, Kansas

AY 2014-01 


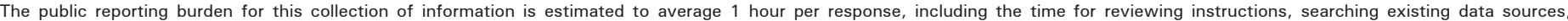

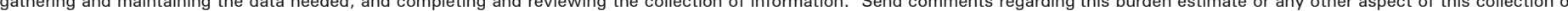

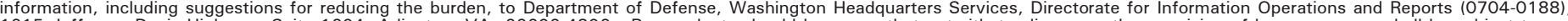

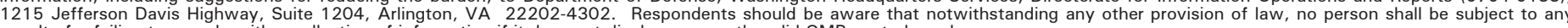
penalty for failing to comply with a collection of information if it does not display a currently valid OMB control number.

PLEASE DO NOT RETURN YOUR FORM TO THE ABOVE ADDRESS.
1. REPORT DATE $(D D-M M-Y Y Y Y)$ 2. REPORT TYPE 22-05-2014
SAMS Monograph
3. DATES COVERED (From - To)
JUN 2013 - MAY 2014

4. TITLE AND SUBTITLE

Lieutenant General Patton’s Seventh Army in Sicily 1943: The Maturation of an American Operational Artist

5a. CONTRACT NUMBER

5b. GRANT NUMBER

5c. PROGRAM ELEMENT NUMBER

6. AUTHOR(S)

5d. PROJECT NUMBER

MAJ Steven L. Chadwick

5e. TASK NUMBER

5f. WORK UNIT NUMBER

7. PERFORMING ORGANIZATION NAME(S) AND ADDRESS(ES)

U.S. Army Command and General Staff College

ATTN: ATZL-SWD-GD

100 Stimson Ave.

Ft. Leavenworth, KS 66027-2301

9. SPONSORING/MONITORING AGENCY NAME(S) AND ADDRESS(ES)
8. PERFORMING ORGANIZATION REPORT NUMBER

10. SPONSOR/MONITOR'S ACRONYM(S)

11. SPONSOR/MONITOR'S REPORT NUMBER(S)

\section{DISTRIBUTION/AVAILABILITY STATEMENT}

Approved for public release; distribution is unlimited.

\section{SUPPLEMENTARY NOTES}

\section{ABSTRACT}

The Sicilian Campaign, codenamed Operation HUSKY, lasted from 10 July to 17 August 1943, and was an important evolutionary step in George S. Patton's maturation as an operational artist. The study of his operational art in Sicily leads to two questions. How did Patton's experience during the Sicilian Campaign influence his ability to understand an operational environment and accurately visualize operations? Furthermore, how did Patton's personal and professional military development prepare him for operations in Sicily? Patton's personal and professional development enabled him to visualize the Seventh Army's advance on Palermo and Messina (the strategic objective in Sicily) prior to the Allied invasion of Sicily, despite his initial limited role in the campaign. In Sicily, Patton's ability to understand and visualize operations allowed him to deviate from the original Allied operational plan to rearrange tactical actions in time and space to seize Messina using several of the elements of operational art. Continued in Abstract.

15. SUBJECT TERMS

George S. Patton, Sicily, Operation HUSKY, Operational art, visualization, professional development.

\begin{tabular}{|c|c|c|}
\hline \multicolumn{3}{|c|}{ 16. SECURITY CLASSIFICATION OF: } \\
\hline a. REPORT & b. ABSTRACT & c. THIS PAGE \\
Unclassified & Unclassified & Unclassified \\
\hline
\end{tabular}

\begin{tabular}{|c|c|}
\hline 17. LIMITATION OF & 18. NUMBER \\
ABSTRACT & OF \\
& PAGES \\
UU & 70 \\
&
\end{tabular}

19a. NAME OF RESPONSIBLE PERSON

19b. TELEPHONE NUMBER (Include area code) 


\section{MONOGRAPH APPROVAL}

Name of Candidate: Major Steven L. Chadwick

Monograph Title: $\quad$ Lieutenant General Patton's Seventh Army in Sicily 1943: The Maturation of an American Operational Artist

Approved by:

Peter J. Schifferle, Ph.D. , Monograph Director

Michael J. Swanson, COL , Seminar Leader

, Deputy Director for Academics

G. Scott Gorman, Ph.D.

Henry A. Arnold III, COL, IN

, Director, School of Advanced Military Studies

Accepted this 23rd day of May 2014 by:

Robert F. Baumann, Ph.D.

, Director, Graduate Degree Programs

The opinions and conclusions expressed herein are those of the student author, and do not necessarily represent the views of the U.S. Army Command and General Staff College or any other government agency. (References to this study should include the foregoing statement.) 


\begin{abstract}
LIEUTENANT GENERAL PATTON'S SEVENTH ARMY IN SICILY 1943: THE MATURATION OF AN AMERICAN OPERATIONAL ARTIST, by MAJ Steven Chadwick, 70 pages.
\end{abstract}

The Sicilian Campaign, codenamed Operation HUSKY, lasted from 10 July to 17 August 1943, and was an important evolutionary step in George S. Patton's maturation as an operational artist. The study of his operational art in Sicily leads to two questions. How did Patton's experience during the Sicilian Campaign influence his ability to understand an operational environment and accurately visualize operations? Furthermore, how did Patton's personal and professional military development prepare him for operations in Sicily? Patton's personal and professional development enabled him to visualize the Seventh Army's advance on Palermo and Messina (the strategic objective in Sicily) prior to the Allied invasion of Sicily, despite his initial limited role in the campaign. In Sicily, Patton's ability to understand and visualize operations allowed him to deviate from the original Allied operational plan to rearrange tactical actions in time and space to seize Messina using several of the elements of operational art.

The analysis of Patton's operational art in Sicily considers his professional military development and the Seventh Army's participation in Operation HUSKY during the planning and execution of the campaign. Patton's personal and professional officer education provided a knowledge base grounded in theory, history, and doctrine. The practical application of his education during his training and operational experiences further developed Patton's ability to understand and visualize operations. Patton used his training and operational experiences in the Mexican Punitive Expedition, World War One, and the interwar maneuvers to develop an understanding for what are now called the elements of operational art. From these experiences Patton gained an appreciation for tempo, operational reach, culmination, lines of operation, basing, and risk which he experimented with throughout his early development. This understanding, nurtured through Patton's early professional development, generated the knowledge required for him to effectively visualize operations during the planning and execution of Operation HUSKY.

Patton's command of the Seventh Army was exceptional, and it represented over thirty-four years of preparation both personally and professionally as an operational artist. During Operation HUSKY Patton utilized his prior experience to execute combined arms operations and employed select elements of operational art to achieve the decisive point of his campaign, the seizure of Palermo. Patton exhibited his most substantial growth as an operational artist with his ability to understand and visualize both the actions of an enemy force and his own operational approach. 


\section{TABLE OF CONTENTS}

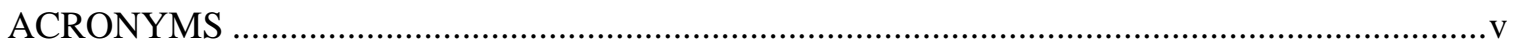

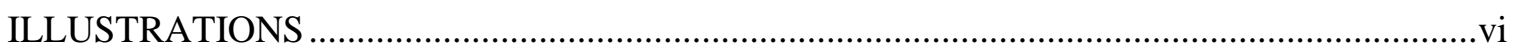

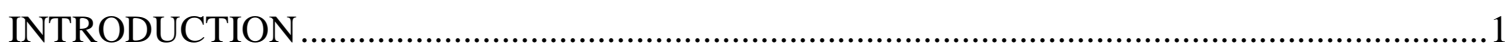

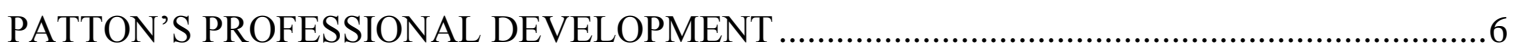

PLANNING FOR THE SICILIAN CAMPAIGN: OPERATION HUSKY .................................19

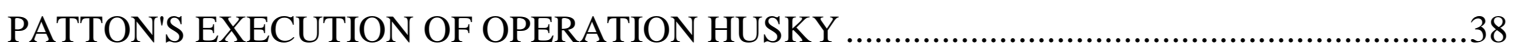

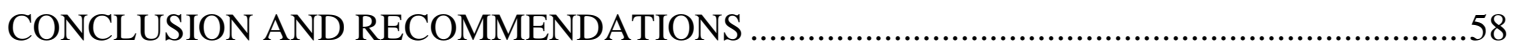

APPENDIX A: GEORGE S. PATTON BIOGRAPHICAL TIMELINE .....................................62

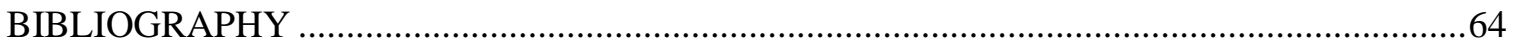




\section{ACRONYMS}

$\begin{array}{ll}\text { AEF } & \text { American Expeditionary Force } \\ \text { AWC } & \text { Army War College } \\ \text { CCOS } & \text { Combined Chiefs of Staff } \\ \text { CGSS } & \text { United States Army Command and General Staff School } \\ \text { COA } & \text { Course of Action } \\ \text { NATAF } & \text { North-West Tactical Air Force } \\ \text { OSS } & \text { Office of Strategic Services } \\ \text { USMA } & \text { United States Military Academy } \\ \text { VMI } & \text { Virginia Military Institute }\end{array}$




\section{ILLUSTRATIONS}

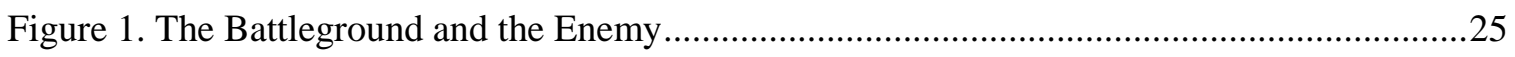

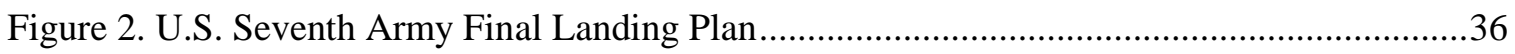

Figure 3. U.S. Seventh Army Assault of Sicily .................................................................. 41

Figure 4. The U.S Seventh Army Clears Western Sicily ........................................................50

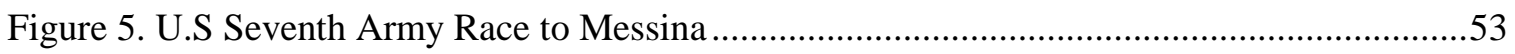




\section{INTRODUCTION}

Many times the question has been asked whether Patton possessed an intuition a sixth sense or whatever- which contributed to the exploits of his commands and to his ability to catch the enemy unaware. If one can call anticipation of enemy reactions based on a lifetime of professional training and on thinking and application "intuition," he had it.

- Brigadier General Oscar W. Koch, G-2: Intelligence for Patton ${ }^{1}$

On 26 December 1944, the lead elements of Lieutenant General George S. Patton's

United States Third Army successfully relieved the besieged 101st Airborne Division in Bastogne during the Battle of the Bulge. To accomplish this, Patton changed his army's direction of attack ninety degrees to the north in just forty-eight hours and attacked the southern flank of the German Fifth Panzer and Seventh Armies in the Ardennes. Prior to the German attack, Patton understood that the German build-up represented something larger than a local German spoiling attack. ${ }^{2}$

Patton's understanding of the enemy and the operational environment allowed him to visualize an operational approach to confront the German threat from the Ardennes prior to the German offensive. $^{3}$

On 19 December, four days into the German offensive, General Dwight D. Eisenhower, Supreme Allied Commander Europe, asked Patton when he could organize a counterattack from

\footnotetext{
${ }^{1}$ Quoted in Oscar W. Koch and Robert Hays, G-2: Intelligence for Patton (Atglen, PA: Schiffer Publishing, 1999), 151.

${ }^{2}$ Charles D. MacDonald, A Time for Trumpets: The Untold Story of the Battle of the Bulge (New York: Bantam Books, 1984), 68-69. On 9 December 1944 Patton's G-2, Colonel Oscar Koch, provided Patton an intelligence estimate based on ULTRA reports, POW interrogations, ground, and air reconnaissance that identified a large concentration of German forces east of the Ardennes. In response, Patton directed his staff to make a contingency plan to counter German threats from the Ardennes.

${ }^{3}$ Headquarters, Department of the Army, ADRP 5-0: The Operations Process (Washington DC: Government Printing Office, May 2012), 3. Defines Commander's visualization as "the mental process of developing situational understanding, determining a desired end state, and envisioning an operational approach by which the force will achieve that end state."
} 
the south. ${ }^{4}$ Patton with three contingency plans in hand responded, "the morning of December 22 with three divisions." ${ }^{5}$ After some debate, Eisenhower agreed, and Patton simply found a telephone and provided his staff a code word to set the Third Army in motion toward Bastogne. General Omar N. Bradley, Patton's commander in Europe, acknowledged a "greatly matured Patton," and his "brilliant effort that characterized Third Army's turnabout in the Bulge."” Patton's ability to understand his environment and visualize operations during the Battle of Bulge demonstrated the maturation of an American operational artist. However, his success in recognizing the German threat in the Ardennes relied heavily on experience gained in his approach to and execution of the Sicilian Campaign in 1943.

The Sicilian Campaign lasted from 10 July to 17 August 1943, and was an important evolutionary step in Patton's development as an operational artist. The invasion of the island of Sicily followed the successful Allied campaign to expel Axis forces from North Africa. Code named Operation HUSKY, the invasion of Sicily was a major Allied amphibious operation followed by a thirty-eight day ground campaign to seize the island from Axis control. During the planning and execution of the Allied campaign in Sicily Patton commanded the United States Seventh Army. The Seventh Army had a minor role in the campaign, while General Sir Bernard Law Montgomery, commander of the British Eighth Army, had the task of capturing the strategically important city of Messina. ${ }^{7}$ The slow advance of the British Eighth Army and the

${ }^{4}$ R. Ernest Dupuy and Trevor N. Dupuy, The Harper Encyclopedia of Military History, $4^{\text {th }}$ ed. (New York: HarperCollins Publishers, 1993), 1217-1218; MacDonald, A Time for Trumpets, 420-421. The German Ardennes Offensive, known as the Battle of Bulge, took place from 16 December 1944 to 16 January 1945. MacDonald provides a detailed account of Eisenhower's famous meeting at Verdun, France on 19 December 1944 to determine the Allied response to the German attack in the Ardennes.

${ }^{5}$ Ladislas Farago, Patton: Ordeal and Triumph (Yardley, PA: Westholme Publishing, 1964), 708.

${ }^{6}$ Omar N. Bradley, A Soldier's Story (New York, Henry Holt and Company, 1951), 473.

${ }^{7}$ Albert N. Garland and Howard M. Smyth, United States Army in World War II: The Mediterranean Theater of Operations, Sicily and the Surrender of Italy (Washington, DC: Center of 
lack of direction from the Allied Ground Force Commander, Sir Harold Alexander, provided Patton an opportunity to seize the initiative in Sicily. ${ }^{8}$

The study of Patton's operational art in Sicily leads to two questions. How did Patton's experience during the Sicilian Campaign influence his ability to understand an operational environment and accurately visualize operations? Furthermore, how did Patton's personal and professional military development prepare him for operations in Sicily? Patton's personal and professional development enabled him to visualize the Seventh Army's advance on Palermo and Messina prior to the Allied invasion of Sicily, similar to his experience in the Ardennes. In Sicily, Patton's ability to understand and visualize operations allowed him to deviate from the original Allied operational plan to rearrange tactical actions in time and space to seize Messina using the elements of operational art.

Current U.S. Army doctrine describes operational art as "how commanders balance risk and opportunity to create and maintain the conditions necessary to seize, retain, and exploit the initiative and gain a position of relative advantage while linking tactical actions to reach a strategic objective." Commanders apply operational art using mission command through a process of understanding, visualizing, describing, directing, leading, and assessing operations. ${ }^{10}$ Throughout Patton's years of service before and during World War Two, U.S. Army doctrine did

Military History, 1965), 53. Allied planners considered Messina a strategic objective because it linked Sicily to mainland Italy. The seizure of Messina would deny Axis defenders their withdrawal route, reinforcements and resupply.

${ }^{8}$ John Keegan, The Second World War (New York: Penguin Books, 1989), 346-349.

${ }^{9}$ Headquarters, Department of the Army, ADRP 3-0: Unified Land Operation (Washington DC: Government Printing Office, October 2011), 10.

${ }^{10}$ Headquarters, Department of the Army, ADRP 6-0: Mission Command (Washington DC: Government Printing Office, May 2012), 1. Mission command is the exercise of authority and direction by the commander using mission orders to enable disciplined initiative within the commander's intent to empower agile and adaptive leaders in the conduct of unified land operations. 
not recognize the operational level of war, and did not teach operational art as a concept. ${ }^{11}$

However, Patton through his personal study of warfare, professional military education, training, and operational experience developed an instinctive understanding of the application of operational art. The most essential element of this process is visualization. In Sicily, Patton's understanding of the operational environment and combined arms operations allowed him to visualize an operational approach that demonstrated several elements of operational art including: tempo, operational reach, culmination, lines of operation, basing, risk, and decisive points. ${ }^{12}$

The analysis of Patton's operational art in Sicily considers his professional military development and the Seventh Army's participation in Operation HUSKY during the planning and execution of the campaign. The first section, Patton's Professional Development, analyzes his professional development through a study of his professional military education, as well as his operational and training experiences. The study of Patton's professional military education describes his experiences from his time at the United States Military Academy at West Point through the Army War College. His professional military education, primarily at the Command and General Staff School and Army War College, provided him an understanding of doctrine. In addition, his education taught him how to plan for and employ large formations, and developed his decision making skills. Patton's operational and training experiences during the Mexican Punitive Expedition, World War One, and the interwar period introduced him to combined arms

\footnotetext{
${ }^{11}$ Peter J. Schifferle, America's School for War: Fort Leavenworth, Officer Education, and Victory in World War II (Lawrence, KS: University Press of Kansas, 2010), 63. Describes how operational art during the interwar period implied mastering a mechanical set of competencies, and military skill was the methodical application of military force. The practical applicatory method of instruction taught at CGSS exposed students like Patton to an early understanding of operational art through mechanical application.

${ }^{12}$ Headquarters, Department of the Army, ADRP 5-0, 1-4. An operational approach is a description of the broad actions the force must take to transform current conditions into those desired at end state. Headquarters, Department of the Army, ADRP 3-0, 4-2-4-9. Provides definitions for the elements of operational art.
} 
operations. This knowledge generated the foundational experience required to understand and visualize operations in Sicily.

The next section, Planning for the Sicilian Campaign: Operation HUSKY, focuses on the strategic goals for the Sicilian Campaign and Seventh Army's planning for Operation HUSKY. The study of the early planning for Operation HUSKY provides an understanding of the difficulties of planning the campaign in Sicily while Patton and the other principle commanders remained engaged with operations in North Africa. The final plan for HUSKY describes the initial limited role given to Patton's Seventh Army. Despite the limited role, Patton through his understanding of the operational environment, and the conditions required for the Allied endstate, visualized a Seventh Army advance on Messina. Patton's understanding of the strategic importance of Messina led him to envision a branch plan to seize an intermediate objective at Palermo. In this plan, Palermo became the decisive point of Patton's campaign and enabled his final advance on Messina using an indirect approach.

The third section, Patton's Execution of Operation HUSKY, examines the execution of the Sicilian Campaign comparing the original Seventh Army plan with the actual events on the ground. Following the amphibious landings and the establishment of a beachhead, Patton began to set the conditions for a direct approach to Messina. However, a boundary dispute between the United States Seventh Army and the British Eighth Army denied Patton his direct approach. The altered conditions on Sicily stimulated Patton to execute his visualized branch plan to seize Palermo as an intermediate objective to Messina. The capture of Palermo gave Patton the initiative in Sicily, which he struggled to sustain during his final advance on Messina. The section includes discussion on Patton's execution of mission command and concludes with his lessons learned in Sicily.

The conclusion reviews the critical elements that contributed to Patton's maturation as an operational artist in Sicily. Recommendations include a discussion on how the study of Patton's 
operations in Sicily can enhance our understanding of how to apply operational art in the current operational environment. However, prior to beginning a study of Patton's maturation as an operational artist during the Sicilian Campaign, it is important to understand how his personal and professional military development influenced his ability to visualize operations in Sicily.

\section{PATTON'S PROFESSIONAL DEVELOPMENT}

By the time Lieutenant General George S. Patton led the United States Seventh Army into Sicily in 1943 he had the benefit of thirty-four years of leadership experience. Patton's military career began at the Virginia Military Institute (VMI) and culminated with the German defeat in Western Europe. To understand how Patton visualized the Sicilian Campaign, it is important to recognize his life-long dedication to the study of warfare. Patton's personal and professional military education provided a knowledge base grounded in theory, history, and doctrine. The practical application of his education during his training and operational experiences further developed Patton's ability to understand and visualize operations. The section begins with Patton's primary military education including the United States Military Academy (USMA) at West Point, the United States Command and General Staff School (CGSS), and the Army War College (AWC). Next, Patton's training and operational assignments such as his time during the Mexican Punitive Expedition, World War One, and the interwar period are informative and facilitate an understanding of how he learned to visualize operations.

\section{Professional Military Education}

George S. Patton, Jr. determined that he wanted to be a soldier early in life and in this career choice he never wavered. At West Point, Patton initially struggled academically and failed his first year. ${ }^{13}$ However, by graduation he had developed several practices that would prove

${ }^{13}$ Carlo D’Este, Patton: A Genius for War (New York: Harper Perennial, 1996), 44-47. Patton did not attend formal schooling until he was twelve resulting later in significant academic difficulties during his earlier years at West Point. 
critical to his ability to visualize operations. During his first year, Patton began the life-long practice of journal keeping on notes cards. On his notecards, Patton reflected upon his course work and personal reading, which led to a plan to start a professional library. ${ }^{14}$ Patton's earliest readings and journal entries allowed him to begin developing his own theory of warfare, which he continued to refine throughout his career. In 1909, Patton made a list of six "Qualities of a Great General" to emulate which included being tactically aggressive (loves to fight), strength of character, steadiness of purpose, acceptance of responsibility, energy, good health and strength. Patton spent the rest of his career attempting to adhere to these character traits and his personal reading on leadership reflected his effort. ${ }^{15}$

Additionally, Patton's course work and personal reading exposed him to theorists such as Antoine-Henri Jomini that have also influenced our current doctrine of operational art in ADRP 3-0, Unified Land Operations, 2012. For example, Patton studied Elements of Strategy by Lieutenant Colonel G.J Fiebeger, a USMA professor of Engineering, which included Jomini's concepts of decisive points, basing, and lines of operation. ${ }^{16}$ Patton would later use each of these concepts during his campaign in Sicily. Despite his early academic challenges, Patton graduated from West Point in 1909 ranked 46 of 103 cadets earning a commission in the Cavalry. ${ }^{17}$

\footnotetext{
${ }^{14}$ Roger H. Nye, The Patton Mind: The Professional Development of an Extraordinary Leader (New York: Avery Publishing Group, 1993), 14-15. Patton first book list included seventeen books including many prominent theorists and generals such as Antoine-Henri Jomini, Napoleon Bonaparte, Henry Lloyd, Colmar von der Goltz and Emory Upton.

${ }^{15}$ Nye, The Patton Mind, 18-21.

${ }^{16}$ G. J. Fiebeger, Elements of Strategy (New York: United States Military Academy Press, 1906), $7,21-23,110$. A base of operations is "the portion of the country from which the army obtains its reinforcements and resources." Line of operations is "any route which penetrates into the defender's country and along which an army can be moved and supplied." Decisive point is "a strategic point, whose capture will have a very important effect upon the political or military situation."

${ }^{17}$ Stanley P. Hirshson, General Patton: A Soldier's Life (New York: Harper Perennial, 2002), 48.
} 
After graduation, Patton served in the $15^{\text {th }}$ Cavalry at Fort Sheridan, Illinois and historic Fort Myer, near Washington D.C. At Fort Myer, Patton and his bride Beatrice Ayer mingled with the social elite in the capitol. Patton competed in the 1912 Olympics in Stockholm followed by an opportunity to train in swordsmanship at the famous French Cavalry School of Application in Saumur. While in France, Patton conducted a detailed reconnaissance of the Bocage region in Normandy. Based on his findings, he wrote a report focused on significant road networks that enhanced his ability to visualize an operational environment. Patton used the report 30 years later commanding the United States Third Army in the same area. ${ }^{18}$

In 1913 Patton attended the respected Mounted Service School at Fort Riley for two years as both a pupil and instructor. Later in 1923 he attended the Advanced Course at the Cavalry School graduating second in his class, which earned him a slot to the coveted Command and General Staff School in September 1923. CGSS was an important discriminator for officers during the interwar period and a point of departure for the Army's most promising officers. The CGSS curriculum focused on preparing officers for positions as commanders and staff officers at the division and corps level. To this end, the CGSS curriculum used difficult tactical decision making problems and war-games to develop decision making skills and improve student confidence handling large formations. ${ }^{19}$ Michael R. Matheny in Carrying the War to the Enemy: American Operational Art to 1945 argues that CGSS recognized the three levels of war and incorporated elements of operational art into their curriculum during the interwar period. The school's focus on the application of combat power within a theater of operations, operational

\footnotetext{
${ }^{18}$ Farago, Patton: Ordeal and Triumph, 65-66. Patton went to the French Cavalry School of Application using his own funds to learn swordsmanship from their Master of Arms. Patton traveled William the Conqueror's invasion route during his reconnaissance, but he used a vehicle anticipating the next war in the region would include automobiles.

${ }^{19}$ Schifferle, America's School for War, 64-68.
} 
phasing, and the importance of logistics foreshadowed our current doctrinal understanding of operational art and introduced Patton to the operational level of war. ${ }^{20}$

Patton received further exposure to the operational level of war reading Colonel William Naylor's Principles of Strategy. Naylor, the CGSS Director, described how military operations group actions "for the purpose of reaching a certain goal, capturing a certain point or defeating a certain group of the enemy." ${ }^{21}$ He goes on to say how groups of actions are connected by a "fundamental idea," and how a general must understand "the main purpose of the campaign" given the larger context of the political and military situation. ${ }^{22}$ In essence, Naylor provided Patton a description of operational art. ${ }^{23}$ Additionally, Naylor introduced Patton to another element of operational art with his discussion of points of culmination. Naylor defines the point of culmination as "an inevitable process of weakening, at a point which does not assure any future success, or, in other words, the point of culmination." ${ }^{24}$ In the end, Patton met his high expectations for professional development and graduated with honors ranked 25 out of 248 officers in his class. ${ }^{25}$

${ }^{20}$ Michael R. Matheny, Carrying the War to the Enemy: American Operational Art to 1945 (Norman, OK: University of Oklahoma Press, 2011), 55. Mathney states "The Staff School clearly recognized three levels of war and reflected several key elements of operational art in its instruction." Inncluding center of gravity, offensive culmination, and phasing as the elements of operational art taught.

${ }^{21}$ William Naylor, Principles of Strategy (FT. Leavenworth, KS: The General Service School's Press, 1921), 149.

${ }^{22}$ Naylor, Principles of Strategy, 149-157; Nye, The Patton Mind, 59. Discusses Patton's interests in strategic and operational history.

${ }^{23}$ Headquarters, Department of the Army, ADRP 3-0, 4-1. Similar to Naylor's description current doctrine defines Operational art as "the pursuit of strategic objectives, in whole or part, through the arrangement of tactical actions in time, space, and purpose."

${ }^{24}$ Headquarters, Department of the Army, ADRP 3-0, 4-8. Culminating point "is the point in time and space at which a force no longer possesses the capability to continue its current form of operations."

${ }^{25}$ Hirshson, A Soldier's Life, 171. 
Patton's professional military education culminated at the prestigious Army War College (AWC) in 1932. The mission of the AWC during the interwar period was to train officers in the preparation and execution of combat operations at the army and theater levels, which would prove invaluable for Patton in Sicily as a new army commander. ${ }^{26}$ The War College focused on problem-solving exercises based on real war plans maintained by the War Department. ${ }^{27}$ Students worked in committees, but were not graded, which prompted many of Patton's classmates to view the year as an opportunity to rest. Patton, a tireless student of war, approached his committee work with a level of intensity that characterized his approach to professional development. ${ }^{28}$

At AWC Patton wrote a paper entitled "The Probable Characteristics of the Next War and the Organization, Tactics, and Equipment Necessary to Meet Them.” Patton's paper used history as a guide to compare and contrast the merits of mass (conscripted and ill-trained) and professional (trained regulars) armies. Patton's thesis expressed his preference for smaller professional armies that were highly trained, self-contained, and mobile for future wars. Furthermore, Patton shared his opinions on combined arms warfare. For example, Patton described how the sequencing of infantry, cavalry, and tank movements supported by artillery can extend the depth of flank attacks or turning movements. ${ }^{29}$ He also addressed the necessity of “indoctrinated initiative and simple, short orders" given the dispersion and speed of combined arms operations. This is similar to the concepts of "mission orders" and "disciplined initiative" in

\footnotetext{
${ }^{26}$ Nye, The Patton Mind, 96-97. Patton continued to create notecards like his West Point days. At AWC he made notecards of his personal ideas of warfare and his visualization of future war.

${ }^{27}$ Schifferle, America's School for War, 34.

${ }^{28}$ Hirshson, A Soldier's Life, 202.

${ }^{29}$ George S. Patton, 29 February 1932, "The Probable Characteristics of the Next War and the Organization, Tactics, and Equipment Necessary to Meet Them," in Military Essays and Articles, ed. Charles M. Province (San Diego: The George S. Patton, Jr. Historical Society, 2002), 187.
} 
mission command today. ${ }^{30}$ In essence, the general theme for Patton's paper is his vision of future warfare, and this indicates his efforts to understand the future operational environment. His recommendations provide his visualization to meet the challenges of future wars.

\section{Mexican Punitive Expedition: 1916- 1917}

While Patton's professional military education was critical to his visualization during the Sicilian Campaign, a study of his development as an operational artist would be incomplete without consideration of his operational experiences. Patton first experienced the hardships of combat during the Mexican Punitive Expedition where he served as an aide to Brigadier General John J. Pershing. Patton's most famous action during the campaign occurred in May 1916 while he led a patrol of three automobiles to purchase corn. During the mission, Patton decided to search a local ranch for a Villista Officer he was tracking that resulted in a short firefight, the death of three bandits, and the first time American troops used motor vehicles in combat. During the campaign, Patton learned many important lessons that would influence him throughout his career including the importance of logistics, precise staff work, the potential of air reconnaissance, and motorization. ${ }^{31}$ Additionally, Patton gained a powerful mentor in General Pershing who admired his aggressiveness. In return, Patton viewed Pershing as the model combat leader who reinforced his beliefs in troop discipline, personal example, and the importance of organizational skills. ${ }^{32}$

\footnotetext{
${ }^{30}$ Patton, "The Probable Characteristics", Military Essays and Articles, 188; Headquarters, Department of the Army, ADRP 6-0, 2-1.

${ }^{31}$ Martin Blumenson, Patton: The Man Behind the Legend, 1885-1945 (New York: William Morrow, 1985), 83-87. Blumenson makes the point that Patton was the first U.S. Army officer to use an automobile in combat. He believes this experience was formative for Patton and foreshadowed his expertise in mobile warfare later.

${ }^{32}$ Patton, 1924, "Personal Glimpses Of General Pershing," in Military Essays and Articles, 285289; D’Este, Patton: A Genius for War, 164-165.
} 
World War One: 1917-1919

The U.S. entry into World War One on 6 April 1917 provided Patton with his second opportunity to experience combat. Patton's close relationship with Pershing resulted in an appointment to his staff and he joined the advance elements of the American Expeditionary Force (AEF) sailing for France. American observations of British and French tank development led to discussions among staff officers of the possibility to obtain tanks for the AEF, and Patton submitted his name for consideration if the AEF developed a tank force. ${ }^{33}$ In a letter to Pershing Patton listed his qualifications for tank service as his experience with gas engines, ability to speak French, and his cavalry background given the similarities of light tank employment to cavalry operations. To add emphasis, Patton included that he was "the only American who has ever made an attack in a motor vehicle." ${ }^{34}$ When the AEF decided to establish a Tank Corps, Patton faced a dilemma. He could leave the cavalry and transfer to the infantry, or take a position in the newly created American Tank Corps. After much anguish Patton chose the Tank Corps saying to his father, "there would be a hundred majors of infantry but only one of light tanks," beginning his career as America's preeminent tank commander. ${ }^{35}$

Patton approached his task to build an American tank force with his usual determination and efficiency. He established the American tank school in Langres following his attendance of both the British and French tank schools and observed tanks in action whenever possible. He interviewed the British veterans of the Battle of Cambrai, at that time the largest employment of tanks in battle, including the future theorist Captain J.F.C Fuller. Following a month of intensive

${ }^{33}$ Blumenson, Patton, 96.

${ }^{34}$ D'Este, Patton: A Genius for War, 204. Patton referred to his experience using an vehicle in combat during the Mexican Punitive Expedition.

${ }^{35}$ Hirshson, A Soldier's Life, 101. Throughout his life Patton consistently consulted his father for advice concerning decisions about his career in the Army. 
study, Patton submitted a detailed report of his observations entitled Light Tanks to recommend the organization, equipment, training, and tactics for the Tank Corps. ${ }^{36}$ Patton observed the offensive potential of the tank to support the penetration of an enemy force and exploit success in depth. Based on this observation Patton said, "If resistance is broken and the line pierced the tank must and will assume the role of pursuit cavalry and ride the enemy to death," and this foreshadowed his views on tempo during the Sicilian Campaign. ${ }^{37}$

Despite an initial lack of tanks for training, Patton eventually procured enough equipment and men to organize the $1^{\text {st }}$ Light Tank Battalion and later $1^{\text {st }}$ Tank Brigade, which he personally commanded. Patton tirelessly trained with his men as he developed the tactics to employ tanks in combat. He executed joint maneuvers with infantry and when possible displayed the tank's capability for officers attending the various schools in Langres. ${ }^{38}$ Patton's experience as the light tank school commandant further defined his beliefs on the proper use of armor which he would soon test in combat. ${ }^{39}$ Patton successfully led his tank brigade during both the St. Mihiel and Meuse-Argonne Offensives. In each battle Patton led by example, personally directing his tankers on foot until wounded on the first day of the Meuse-Argonne Offensive on 26 September 1918. As he envisioned, his unit was able to assist the infantry to breach the German line and then

\footnotetext{
${ }^{36}$ Patton to The Chief of the Tank Service, 12 December 1917, in Military Essays and Articles, 85. D'Este, Patton: A Genius for War, 208.

${ }^{37}$ Patton to The Chief, in Military Essays and Articles, 104; Headquarters, Department of the Army, ADRP 3-0, 4-7. "Tempo is the relative speed and rhythm of military operations over time with respect to the enemy."

${ }^{38}$ Nye, The Patton Mind, 45; Schifferle, America's School for War, 12-13. Patton was a student/instructor at the General Staff School at Langres while simultaneously commanding the American Tank School. The General Staff School was a three month course. The education Patton received there was much like his later CGSS experience, but more focused on practical skills geared to specific staff positions.

${ }^{39}$ Blumenson, Patton, 105-108.
} 
exploit the penetration. However, the broken terrain and limited operational reach of the Renault Tank ultimately forced his brigade to culminate. ${ }^{40}$

Patton's experiences reinforced prior lessons from Mexico concerning the importance of logistics, but more significantly his view on the proper place for a commander in battle, at the decisive point of an operation. His brigade's culmination on the first day of the Meuse-Argonne Campaign provided a practical example to reinforce his future lessons from Naylor at CGSS. However, Patton derived his most important lessons from his combined arms experience. He learned the value of tanks and infantry working in coordinated teams with supporting fires. But his training at the General Staff School at Langres and his own combat experience also taught him the necessity of integrating logistics, signalers, and aviation into the combined arms fight.

Patton visualized the tank's potential to increase the tempo of offensive operations through speed and shock action to attack an enemy in depth. Patton would continue to reflect on the lessons of World War One during the interwar period. ${ }^{41}$

Patton's Interwar Period: 1919- 1941

Based on his World War One experiences, Patton advocated for an independent tank corps as an integral component of a larger combined arms effort after the war. In an article called "Tanks in Future Wars" written during the interwar period Patton compared the use of tanks in combined arms warfare to a musical band:

There is no belief on the part of any tank officer that the tank has replaced in the least degree any one of the existing arms. It is distinctly a new instrument added to the full chorus of the military band. But having appeared, the new pieces, composed by

${ }^{40}$ Edward M Coffman, The War To End All War: The American Military Experience in World War I (Lexington, KY: The University Press of Kentucky, 1998), 312-313; Nye, The Patton Mind, 47. The combination of the loss of Patton and a tank repair rate of $123 \%$ forced the brigade to culminate. The $1^{\text {st }}$ Tank Bde would fight for fourteen more days and of the original 834 men only 80 were combat effective.

${ }^{41}$ D'Este, Patton: A Genius for War, 229-247. 
future generals, will demand the peculiar tone of the tank instrument for the proper rendition of their compositions. ${ }^{42}$

In his fight for the Tank Corps, Patton met one of the few other officers that understood the potential of armored formations in the post-World War One army, Major Dwight D. Eisenhower, who commanded a stateside tank school during the war. ${ }^{43}$ Their mutual enthusiasm for mechanization established their friendship and the two future World War Two commanders often engaged in spirited debates on doctrinal and policy matters. Unfortunately, the National Defense Act of 4 Jun 1920 ended the argument to maintain the Tank Corps as a separate entity and relegated tanks to the Infantry branch. The decision to place tanks under control of the infantry prompted Patton to return to the Cavalry. ${ }^{44}$

During the interwar period Patton served in numerous staff positions in Hawaii and Washington D.C. along with cavalry commands in the $3^{\text {d }}$ U.S. Cavalry and $5^{\text {th }}$ U.S. Cavalry Regiments. The lack of activity following World War One led Patton to contemplate retirement from the Army. The outbreak of World War Two in Europe stimulated the newly promoted Chief of Staff of the Army, George C. Marshall, to expand the armored force in the United States Army. Marshall's recollections of Patton commanding the $1^{\text {st }}$ Light Tank Brigade at St. Mihiel in 1918 earned him a place on the short list of officers to support the generation of two armored divisions led by another proponent of mechanized warfare, General Adna Chaffee. Patton took

${ }^{42}$ Patton, "Tanks In Future Wars," in Military Essays and Articles, 104.

${ }^{43}$ E.K.G Sixsmith, Eisenhower as Miliary Commander (New York: Stein and Day Publishers, 1972) 5-6; Farago, Patton: Ordeal and Triumph, 111; D'Este, Patton: A Genius for War, 289. Patton and Eisenhower met for the first time in 1919 at Camp Meade. Following World War One Patton commanded a battalion of light tanks in the $304^{\text {th }}$ Brigade and Eisenhower commanded a battalion of Mark VIII Liberty Tanks in the same brigade.

${ }^{44}$ Robert S. Cameron, Mobility, Shock, and Firepower: The Emergence of the U.S. Army's Armor Branch 1917-1945 (Washington, DC: Center of Military History, 2008), 14. 
command of an armored brigade in the $2^{\text {nd }}$ Armored Division at Ft. Benning nearly twenty years after he created the first American tank force. ${ }^{45}$

In September 1940 Patton was selected to command the $2^{\text {nd }}$ Armored Division. Reminiscent of his World War One experience, Patton assumed his post with immense energy and immediately promulgated a strenuous training regimen and strict discipline to turn his division into an effective combat force. Patton's first opportunity to test his armored force came in June 1941 during the Tennessee maneuvers. He understood that his performance would be critical to the future of American armor given the debate between advocates of tanks and antitank weapons. The first action of the exercise was unremarkable when Patton's division failed to penetrate the opposing force's infantry. However, despite significant criticism for his early handling of the division, he re-doubled his efforts and executed a combined arms attack (armor, infantry, artillery, and combat engineers) to envelope the opposing force and cut their line of communication. ${ }^{46}$ In just nine hours his division captured the opposing force commander and the exercise ended twelve hours ahead of the time allocated.$^{47}$ The success of Patton's second effort in Tennessee reflects the synthesis of his ideas on combined arms operations presented in his AWC paper in 1932 and his experience as a tank commander in the AEF.

The Louisiana maneuvers in September of 1941 was an army level exercise including over 400,000 troops from twenty-seven divisions divided into the Red and Blue armies. It provided Patton his second opportunity to showcase the capabilities of his division. The exercise consisted of two phases and Patton's mission in the Red army required him to travel along

\footnotetext{
${ }^{45}$ Blumenson, Patton, 140-144; Cameron, Mobility, Shock, and Firepower, 375-383. Armored forces began organizing themselves in combat commands in 1941, but the War Department did not officially approve the combat command structure until September 1943. Nye, The Patton Mind, 115. $2^{\text {nd }}$ Armored Division reorganized into combat commands in March 1941.

${ }^{46}$ Martin Blumenson, The Patton Papers: 1940-1945 (Boston: Da Capo Press, 1974), 34-35.

${ }^{47}$ Cameron, Mobility, Shock, and Firepower, 277; Farago, Patton: Ordeal and Triumph, 161.
} 
severely restricted corridors created by the Louisiana swamp to his objective. This challenge, similar to the restricted roads his forces would use during their approach march to Messina in the Sicilian campaign, and the failed attack taught him several lessons. ${ }^{48}$ During phase two of the exercise, Patton switched armies and followed a plan fashioned by Colonel Eisenhower, Chief of Staff of the Blue army, to seize the army's objective, the town of Shreveport, Louisiana. To accomplish this task, Patton conducted a 350-mile envelopment, which extended to nearly 400 miles to circumvent a washed out bridge. After only five days, the exercise ended during Patton's final approach march to their objective at Shreveport. ${ }^{49}$ Nevertheless, Patton in a lecture to his troops praised their accomplishments, but also acknowledged areas that required improvement when he said, "we still fail to use every weapon every time....Each time we fight with only one weapon where we could use several weapons, we are not winning a battle; we are making fools of ourselves." 50

The last of the great maneuvers of 1941 occurred in the Carolinas from late October through November. The Carolina maneuvers observed the first occasion when the I Armored Corps worked in concert, but its commander, Major General Charles L. Scott, was unable to control the tempo of rapidly moving forces. Patton received mixed reviews during the exercise. Senior observers commended him for his ability to manage the tempo of his operations, but

\footnotetext{
${ }^{48}$ Cameron, Mobility, Shock, and Firepower, 330-331. Patton's attack failed due to a breakdown in communication between reconnaissance elements and the main body at the beginning of the exercise. This resulted in a lack of understanding of enemy dispositions and the nature of the terrain. This led Patton to attack in open terrain against enemy anti-tank guns and artillery that ended in failure.

${ }^{49}$ D'Este, Patton: A Genius for War, 395-397.

${ }^{50}$ Blumenson, The Patton Papers: 1940-1945, 43. Patton's lecture to his troops reflects the inconsistent employment of combined arms operations. Field Service Regulations 1923 and 1939 outline the sequencing of combined arms operations such as the positioning of artillery to support attack and reconnaissance to determine the composition and disposition of enemy forces. Patton understood these concepts as evident from AEF experience and AWC paper, but he failed on several occasions to effectively employ reconnaissance assets resulting in poor understanding of the operational environment.
} 
admonished him for spending too much time away from his command post. Chief of Staff of the Army George C. Marshall emerged from his observations of Patton convinced he was destined for higher command. ${ }^{51}$ As a result of his performance, Patton assumed command of the I Armored Corps, which he later took to the Desert Training Center in anticipation for operations in North Africa. There Patton continued to perfect his understanding of mobile warfare and ability to command and control large formations. ${ }^{52}$

Major General George S. Patton's participation in the maneuvers of 1941 was the culmination of his personal and professional military development during the interwar period. The exercises provided Patton an opportunity to apply the lessons cultivated during his years of personal and professional military education to align tactical actions to accomplish a military objective ${ }^{53}$ His operational experience in Mexico and France during World War One taught Patton the offensive potential of mechanization. Patton validated his theory concerning the proper employment of armor to exploit an adversary's rear area in depth through continuous attacks. To enable these operations Patton learned to apply a combined arms approach to operations. Patton's capacity for combined arms operations is facilitated by his rudimentary understanding of tempo, decisive points, lines of operation, basing, culmination, and operational reach. This understanding, nurtured through Patton's early professional development, generated the knowledge required for him to visualize operations during the planning and execution of the Sicilian Campaign. However, before we study Patton's operational art in Sicily, it is essential to

${ }^{51}$ D'Este, Patton: A Genius for War, 400-401.

${ }^{52}$ Hirshson, A Soldier's Life, 257-259.

${ }^{53}$ Naylor, Principles of Strategy, 149. Patton's study and reflection of Naylor's rudimentary explanation of operational art during his time at CGSS provided him a resource to learn how to link tactical actions to objectives. 
study the strategic context that guided the Allied decision to invade Sicily in the first place and the subsequent planning for Operation HUSKY.

\section{PLANNING THE SICILIAN CAMPAIGN: OPERATION HUSKY}

The British considered an invasion of Sicily in November 1940 codenamed Operation INFLUX. Later in October 1941, the British again considered an attack on Sicily, but it did not materialize due to the German reinforcement of Sicily and a lack of landing craft. The plans for Operations INFLUX and WHIPCORD would later provide the foundation for Operation HUSKY. ${ }^{54}$ To study the development of the plans for HUSKY, and more specifically Patton's Seventh Army plan, this section analyzes three specific phases of planning. First, it is necessary to identify the strategic objectives for Operation HUSKY and the larger context that led to their selection. Next, this section will analyze the initial plan formulated for Husky and the role established for Patton's Seventh Army. The last part of the section examines the final plan for HUSKY, and its implication on Patton's visualization for how the campaign would progress.

\section{The Strategic Context for Operation HUSKY}

In January 1943, American President Franklin D. Roosevelt and British Prime Minister Winston Churchill made the decision to invade Sicily at the Casablanca Conference. Their decision ended a strategic debate between the American Joint Chiefs of Staff led by George C. Marshall and General Sir Alan Brooke, the British Chief of Staff. General Marshall had advocated for an invasion of Northern France in 1943 as the most direct approach to confront Nazi Germany and relieve pressure off the beleaguered Russians on the Eastern Front. ${ }^{55}$ Conversely, the British preferred an indirect approach to confront Germany at its weakest points.

\footnotetext{
${ }^{54}$ Ian Blackwell, Battle for Sicily: Stepping Stone to Victory (South Yorkshire, Pen and Sword Books, 2008), 11. Germans moved reinforcements on Sicily to protect their airfields located on Sicily.

${ }^{55}$ Samuel W. Mitchum, Jr. and Friedrich Von Stauffenberg, The Battle of Sicily: How the Allies Lost Their Chance for Total Victory (Mechanicsburg, PA: Stackpole Books, 1991), 9.
} 
Brooke designed the peripheral strategy that would continue the troop build-up in England while simultaneously continuing operations in the Mediterranean oriented against Sicily, Sardinia, Italy, and the Balkans. ${ }^{56}$ In the end, Marshall acquiesced to the invasion of Sicily due to the large amount of Allied troops available in North Africa, and the infeasibility of a cross-channel attack on Northern France in $1943 .{ }^{57}$

However, the Allies did agree upon the following strategic outcomes for Operation HUSKY: the occupation of Sicily to make Mediterranean lines of communication more secure, divert German pressure from the Eastern Front, intensify pressure on Italy, and create the conditions to enlist Turkey as an active ally. ${ }^{58}$ During the last few days of the Casablanca Conference Allied leadership settled on 25 July 1943 as the execution date for Operation HUSKY. The last decision at Casablanca concerned the Allied Command structure for the operation. The Combined Chiefs of Staff (CCOS) selected General Eisenhower as the Supreme Commander. Following the conference, they directed Eisenhower to create a headquarters to plan Operation HUSKY and provide recommendations for subordinate command positions to permit detailed planning. ${ }^{59}$

${ }^{56}$ Garland and Smyth, Sicily and the Surrender of Italy, 6.

${ }^{57}$ Casablanca Conference (Casablanca, Morocco), Papers and Minutes of Meetings, 14-24 January 1943, meeting of 18 January 1943, 209. Marshall was concerned about the lack of an Allied grand strategy when he asked "Was an operation against Sicily merely a means towards an end or an end in itself? Is it to be a part of an integrated plan to win the war or simply taking advantage of an opportunity?" The Allies never answered Marshall's question, and Sicily was the only operation agreed on at Casablanca.

${ }^{58}$ Casablanca Conference, Papers and Minutes of Meetings, 16.

${ }^{59}$ S.W.C Pack, Operation Husky: The Allied Invasion of Sicily (New York: Hippocrene Books, 1977), 21. The Combined Chiefs of Staff selected General Eisenhower as the Supreme Commander, and the following officers: the Deputy Supreme Commander and ground force commander Sir Harold Alexander, the Allied Naval Commander Admiral of the Fleet Sir Arthur Cunningham, and the Allied Air Commander Air Chief Marshal Arthur Tedder to lead Operation HUSKY. 


\section{The Initial Plan: Operation HUSKY}

In late January 1943 Eisenhower established a planning group and gave them the task of creating an actionable plan from the conceptual plan developed by the British Joint Planning Staff for the Casablanca Conference. ${ }^{60}$ The newly created planning headquarters held their first meeting at the St. George's Hotel in Algiers, and from these humble beginnings took the name Force 141 for their hotel room number. The CCOS directive required two joint headquarters for the operation, one British and the other American, and Eisenhower recommended the principle subordinate commanders. In early February the CCOS approved Eisenhower's nominations and General Sir Bernard Montgomery, commander of the British Eighth Army, would command the Eastern Task Force. For the American Western Task Force, Eisenhower selected soon-to-be Lieutenant General George S. Patton for command. Patton commanded the U.S. I Armored Corps, which was not engaged in operations in Tunisia and its staff was readily available to plan the American involvement in HUSKY. ${ }^{61}$

Before the Casablanca Conference, Patton had distinguished himself as the commander of the Western Task Force for Operation TORCH, the Allied invasion of French North Africa in November 1942. Following his capture of Casablanca, Patton displayed a propensity for diplomatic relations and provided security for the American and British delegations during the Casablanca Conference, but he longed for another combat command. In early February, Eisenhower called Patton to his headquarters to inform him of his new assignment in Sicily. Patton was ecstatic for the opportunity to command, but given his immense understanding of history he immediately understood the difficulties he would encounter in Sicily when he wrote,

72.

${ }^{60}$ Carlo D’Este, Bitter Victory: The Battle for Sicily, 1943 (New York: Harper Perennial, 1988),

${ }^{61}$ Garland and Smyth, Sicily and the Surrender of Italy, 54-57. 
"apparently I am to command the U.S. force....My luck will have to be pretty good and the Lord on the job to put it over." ${ }^{62}$ His only reservation concerning Sicily was the fact he would be subordinate to a British commander for the operation. Troubled by his perception that the British were dominating operations in Tunisia, Patton remained mistrustful of the British throughout the planning for Operation HUSKY. Nonetheless, Patton approached his responsibilities with his characteristic energy immediately departing for his headquarters in Rabat, unfortunately without taking the opportunity to coordinate with TF 141 at the St. George's Hotel. With Eisenhower's verbal guidance and his own thoughts on the requirements for Sicily, Patton reorganized his staff overnight to plan for HUSKY. However, the American debacle at the Battle of Kasserine Pass in February 1943 would provide Patton a significant distraction, and another opportunity to further develop his operational art prior to Sicily. ${ }^{63}$

On 5 March 1943 Eisenhower summoned Patton to inform that he was to proceed immediately to take temporary command of the U.S. II Corps in Tunisia. In Tunisia, Patton would have his first experience working with a British superior officer. General Harold Alexander, his future commander in Sicily, developed a low opinion of American martial skill during his observation of American forces at the Battle of Kasserine Pass. His low perception of American capabilities would later have implications on the planning and execution of Operation HUSKY. When Patton arrived at II Corps headquarters the following day he had only eleven days to reorganize, retrain, and reestablish a fighting spirit in his command before Alexander expected him to resume the offensive. Patton began his work by enforcing strict standards of appearance

\footnotetext{
${ }^{62}$ Blumenson, The Patton Papers: 1940-1945, 165.

${ }^{63}$ Koch and Hays, G-2: Intelligence for Patton, 38-39; Farago, Patton: Ordeal and Triumph, 236237. Patton moved his headquarters from Casablanca to Rabat and his G-2 section established a team to gather information on Sicily for detailed planning including: topography, enemy defense and order of battle, and the political and economic situation. When Patton left for temporary command the II Corps in Tunisia he tasked his deputy commander, Major General Geoffrey Keyes to continue planning.
} 
and military discipline similar to his previous assignments to establish the command in his image. When the offensive began he emphasized the need for continuous attack and combined arms operations. Moreover, Patton benefited from his understanding of German military capabilities developed from his personal study ${ }^{64}$ Patton's notable victory at the Battle of El Guettar supported his growing confidence to lead large units. However, Alexander's continued lack of confidence in American forces resulted in their limited role, and overly prescriptive orders fueled Patton's dislike for British command despite his personal admiration for Alexander. On 15 April Patton turned over command of II Corps to his deputy commander, Major General Omar Bradley, as previously determined by Eisenhower in order to resume his duties planning for Operation HUSKY.${ }^{65}$ When Patton reflected on his experience in his diary he said, "I have gone 43 days, fought several successful battles, commanded 95,800 men, lost about ten pounds, gained a third star and a hell of a lot of poise and confidence, and am otherwise the same."

With all of the principle commanders actively engaged in ongoing operations in Tunisia, Eisenhower selected British Major General Charles Henry Gairdener as the Chief of Staff for Force 141. Gairdener and his staff used the plans for Operations INFLUX and WHIPCORD along with the conceptual plan created by the British Joint Planning staff for Casablanca to create a series of plans called HUSKY One through Seven. Nevertheless, none of

\footnotetext{
${ }^{64}$ Nye, The Patton Mind, 119. Patton read extensively about German military leaders including Heinz Guderian's Achtung Panzer! and Erwin Rommel's Infantry Attacks to develop an understanding of his enemy.

${ }^{65}$ H. Essame, Patton as Military Commander (London, Da Capo Press, 1974), 82. When Patton returned from Tunisia the invasion was only seven weeks away.

${ }^{66}$ Blumenson, The Patton Papers: 1940-1945, 223.
} 
the plans were acceptable given the divergent interests of the principle air, naval, and ground commanders, and time was running short. ${ }^{67}$

Three considerations drove the planning process for Force 141: ports, airfields, and suitable landing beaches to rapidly concentrate ground forces. The principle ports in Sicily included Messina, Palermo, and Catania with minor ports located at Syracuse and Augusta. Of these ports Messina was the strategic objective for Sicily, given its location two miles from the Italian mainland.$^{68}$ However, Messina's extensive defenses and location placed it outside the range of Allied airpower leaving only Palermo and Catania for consideration. ${ }^{69}$ Air and naval planners deemed the early capture of Axis airfields vital to mission success given the importance of denying their use to Axis air forces, and their necessity to enhance Allied air capability. Allied intelligence identified three major groupings of Axis airfields of Sicily all within 15 miles of the sea. The first, and largest, group was located west of Catania comprising six airfields. The second group consisted of three airfields north of Gela on the southern coast of Sicily at Ponte Olivio, Biscari, and Comisco. The third and final group of six airfields was located in north-west Sicily to protect Palermo (See Fig 1). ${ }^{70}$

${ }^{67}$ Farago, Patton: Ordeal and Triumph, 271; Blackwell, Battle for Sicily, 44; Pack, Operation Husky, 27-33; D'Este, Bitter Victory, 87. TF 141 had to balance the requirements of capturing vital ports (Messina, Palermo, Catania) with the early capture Axis airfields to protect the naval force. In addition Major General Gairdener was not a commander; he was a chief of staff, with no commander providing planning guidance.

${ }^{68}$ Garland and Smyth, Sicily and the Surrender of Italy, 53; Mitchum and Stauffenberg, The Battle of Sicily, 290. Messina linked Sicily to the Italian mainland and it was the largest port on Sicily with a dialy capacity of 1,000 tons. There was a ferry service with four routes crossing the Strait of Messina that could reinforce Sicily with one German and one and a half Italian division per week.

${ }^{69}$ Blackwell, Battle for Sicily, 40.

${ }^{70}$ Ken Ford, Assault on Sicily: Monty and Patton at War (United Kingdom, Sutton Publishing, 2007), 16-17. 


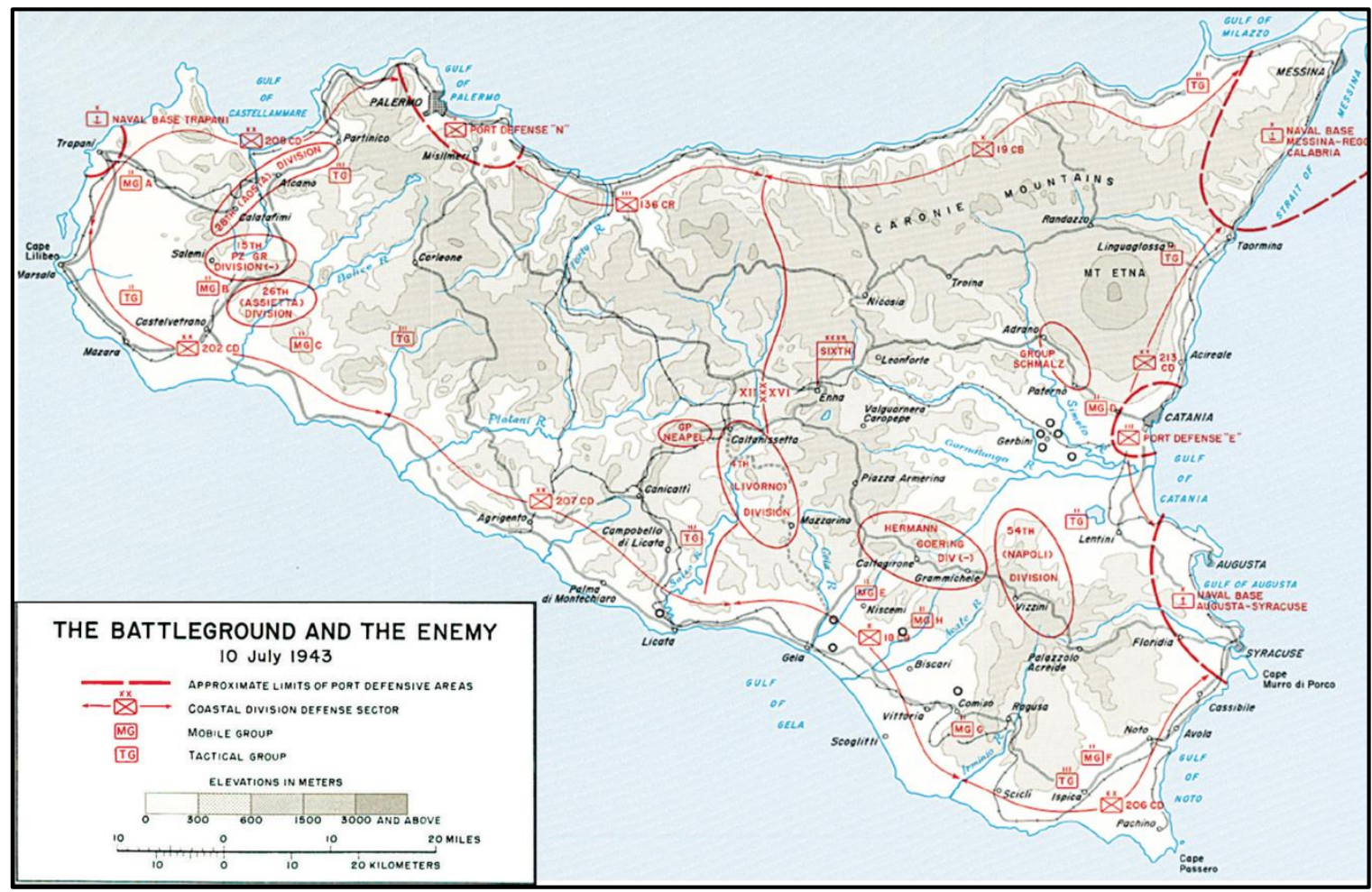

Figure 1. The Battleground and the Enemy

Source: Garland and Smyth, Sicily and the Surrender of Italy, Map I.

The stated requirements for a viable port and the capture of Axis airfields largely dictated the landing beaches, and thus the possible courses of action available to the planners of Force 141. The first course of action (COA) called for dispersed landings in the northwest and southeast of Sicily to capture both Palermo and Catania and place Allied forces in striking range of the Axis airfields. The obvious risk for this COA is that dispersed landings prohibit Allied forces from mutually supporting each other. The second course of action available to Force 141 planners was the concentration of landings in the southeast of Sicily to enable Allied forces to concentrate and overpower Axis forces. The risk inherent to this COA is that Allied forces will be unable to neutralize Axis airfields around Palermo and only one port will be available to sustain the entire Allied ground force. 
Throughout the month of March 1943 Force 141 labored in coordination with five other widely dispersed headquarters on HUSKY Plan Eight. ${ }^{71}$ Simultaneously, all of the principle commanders and sub-commanders remained distracted by on-going operations in Tunisia. Gairdener and his team at Force 141completed the planning for HUSKY Eight in March. HUSKY Eight called for dispersed, but simultaneous landings with the American Western Task Force under Patton landing a division on D-Day at Sciacca on the southwestern coast to secure the western most Axis airfields. The British Eastern Task Force commanded by Montgomery would land three divisions along southeast Sicily to seize airfields at Ponte Olivio, Biscari, and Comisco and the ports Syracuse and Augusta. On D+2 the Americans would land two more divisions near Palermo to capture its large port. By D+3 a fourth British division and an additional brigade would land near Catania to secure the port along with adjacent airfields. HUSKY Eight allowed for the deployment of ten divisions in one week and the seizure of nearly all Axis airfields. Alexander approved of HUSKY Eight based on his staff's analysis that the ports of Catania, Syracuse, and Augusta were incapable of supporting the entire Allied force. On 13 March Eisenhower approved HUSKY Eight and Alexander provided the task force commanders an opportunity to provide feedback. ${ }^{72}$

While Patton did not have any significant objections to HUSKY Eight, Montgomery found the plan completely unacceptable. Following a review of HUSKY Eight, Montgomery stated in a cable to Alexander that "in my opinion the operation breaks every common-sense rule of practical battle fighting and is completely theoretical." ${ }^{, 73}$ Montgomery's primary grievance

${ }^{71}$ D'Este, Bitter Victory, 73; Allied Force Headquarters, Order for Operation HUSKY, 1. The five locations included Force 141 at Algiers, Western TF HQ (U.S.) at Rabat, Morocco, Eastern TF HQ (British) at Cairo, Egypt, as well as the HQs for the $45^{\text {th }}$ Infantry Division in the United States, and $1^{\text {st }}$ Canadian Division planning from England.

${ }^{72}$ Ford, Assault on Sicily, 17-20; Blackwell, Battle for Sicily, 43-44.

${ }^{73}$ D'Este, Bitter Victory, 79-81. 
with the plan concerned the dispersed nature of the British landing across over 100 miles of coastline that left only a third of the British force focused on the ports of Augusta and Syracuse. Instead, Montgomery recommended cancelling the British landing at Gela to strengthen his landings near the ports, but the Allied air and naval commanders objected believing the capture of the airfields north of Gela necessary for the protection of the fleet. To accommodate Montgomery, Alexander decided to transfer the U.S. $3^{\text {rd }}$ Infantry Division landing to Gela and place them under British Command to appease the air and naval commanders. Furthermore, Alexander proposed delaying the American landings until the British secured a foothold on Sicily. Patton, still in Tunisia, protested the loss of a division. Patton understood that losing the landing forces tasked to secure the western airfields would require him to use one of his two other divisions for this mission reducing his force available to seize Palermo. He also realized the American landings were contingent on British success, and there was no consideration of operations beyond the initial landings. ${ }^{74}$

By 10 April Eisenhower approved Alexander's changes to HUSKY Eight despite Patton's concerns. The British eventually provided the extra division and the $3^{\text {rd }}$ Infantry Division returned to Patton, but the staggered landings would remain and the American landings would occur on D+5. Still occupied in Tunisia, Patton accepted the plan, but Montgomery again disapproved the plan. Montgomery, believing that Force 141 planners created the plan based on the assumption of light enemy opposition, wanted to further consolidate his landings. In fact, intelligence planners for HUSKY anticipated heavy resistance from the Italian Sixth Army

\footnotetext{
${ }^{74}$ Garland and Smyth, Sicily and the Surrender of Italy, 58-60.
} 
commanded by General d'Armata Alfredo Guzzoni. On 29 April General Alexander organized a conference in Algiers in an effort to finalize the HUSKY plan. ${ }^{75}$

In the conference Patton called "the famous meeting" on 29 April, the senior leadership planning Operation HUSKY listened to British Lieutenant General Oliver Leese, Commander of the British $30^{\text {th }}$ Corps, briefing for Montgomery. ${ }^{76}$ Montgomery's proposal advocated for a concentrated attack by his British Eastern Task Force in the Gulf of Noto. Additionally, the American Western Task Forces landings should move to the Gela-Licata area from Palermo to allow mutual support. Immediately, Allied Air Commander Air Chief Marshal Arthur Tedder disapproved of the plan given that it left the western airfields in Axis procession to threaten naval forces and Patton's ground force. Patton added to Tedder's objections when he said, 'I would like to stress the point because I am sure that without the airfields, while I may get ashore, I won't live long" to emphasize the risk on Montgomery's proposal on his force. ${ }^{77}$ The meeting concluded when Leese reiterated that Montgomery would not disperse his forces, which only added to Patton's negative view of the British when he wrote in his diary, "to me this is a small-minded attitude and very selfish." ${ }^{" 78}$ Prompted by Tedder, Patton responded that his force was split by more than forty-five miles provoking a frustrated Alexander to respond "that the man on the ground must decide."79 Patton tactfully in his final comment of the day said, "in view of General Alexander's remark, I withdraw mine, but that I felt sure if I refused to attack because my force

\footnotetext{
${ }^{75}$ Blackwell, Battle for Sicily, 44-46.

${ }^{76}$ Blumenson, The Patton Papers: 1940-1945, 235; Garland and Smyth, Sicily and the Surrender of Italy, 62; Ford, Assault on Sicily, 25.

${ }^{77}$ Hirshson, A Soldier's Life, 343.

${ }^{78}$ Blumenson, The Patton Papers: 1940-1945, 236.

${ }^{79}$ Ibid.
} 
was split I would be relieved." ${ }^{80}$ Patton's last comment epitomized his discomfort with the committee style method used by the British for planning. He preferred the leader centric planning process prevalent in available in United States Army doctrine. ${ }^{81}$ The meeting concluded that Eisenhower would have to make the final decision.

On 2 May Eisenhower decided that the final HUSKY plan would incorporate Montgomery's recommendations. The final plan for Operation HUSKY outlined that Montgomery's Eastern Task Force would conduct a concentrated landing in southeastern Sicily. Concurrently, Patton's Western Task Force would land on the southeastern coast at Licata, Gela, and Scoglitti to capture the airfields and advance north to protect the British flank. This plan offered Patton several challenges, primarily the lack of a port to sustain his force. Montgomery agreed to provide tonnage from Syracuse after its capture, but Patton's forces would need to rely on over-the-shore logistics, which at this time was an unproven concept in amphibious operations. Next, Axis air interdiction from airfields in western Sicily posed a significant threat to the American landings. The final challenge facing Patton and his staff was that months of analysis and planning were lost with the change. The change in mission required a new operational plan focused on an area of Sicily unknown to Patton's planners, with a higher plan that failed to address the operation beyond the landings. Acknowledging the difficulties ahead Patton, a proponent of following orders, stated simply "well, we will do it anyway." 82 As a small consolation Eisenhower informed Patton that upon landing in Sicily the American Western Task

${ }^{80}$ Blumenson, The Patton Papers: 1940-1945, 236.

${ }^{81}$ United States War Department, Field Service Regulations United States Army 1923 (Washington, DC: Government Printing Office, 1923) ,4; United States War Department, FM 100-5: Field Service Regulations: Operations. (Washington, DC: Government Printing Office, May 1941), 23. "Decision as to a specific course of action is the responsibility of the commander alone. While he may accept advice and suggestions from any of his subordinates, he alone is responsible for what his unit does or fails to do."

${ }^{82}$ Blumenson, The Patton Papers: 1940-1945, 239. 
Force would become the U.S. Seventh Army placing him on equal footing with Montgomery as an army commander. ${ }^{83}$

\section{The Final Plan: Operation HUSKY}

When Patton and his staff received the change of mission the invasion of Sicily was only two months away. Patton's industrious G-2 intelligence chief, Colonel Oscar Koch, wasted no time and published G-2 Estimate No. 2 on 5 May just two days after the announcement of the change in mission. With all Seventh Army divisions landing at the same time along the southeastern coast of Sicily it was easier to estimate the enemy reaction when compared to the staggered and dispersed assaults of HUSKY Eight. G-2 Estimate No. 2 projected that 15,500 troops supported by 195 pieces of artillery would oppose the Seventh Army landings.

Additionally, the enemy had the capability to reinforce their coastal defense with an additional 34,100 troops within eight hours. Based on terrain and enemy dispositions, further Axis counterattacks would originate from the northwest. ${ }^{84}$

On 9 June Koch and his team published their last formal intelligence estimate. The updated estimate clarified the enemy order of battle for Patton to include an estimated eight to nine Italian divisions and one German division in reserve. Koch further believed German and Italian reserves were task organized into smaller combat groups including three tank battalions, two German and one Italian. Axis air capability included an estimated 800 combat aircraft of which 490 were serviceable all located in airfields within 120 miles of Seventh Army landing beaches. Koch's surprisingly accurate intelligence estimate enabled Patton's understanding of his

\footnotetext{
${ }^{83}$ D’Este, Patton: A Genius for War, 499.
}

${ }^{84}$ Koch and Hays, G-2: Intelligence for Patton, 46. Colonel Oscar Koch started serving as Patton's G-2 during Operation TORCH (The invasion of French Morocco) and remained with him for the duration of World War Two. Koch significantly enhanced Patton's understanding of the environment and the enemy in Sicily. Koch provided Patton with a daily intelligence briefs to augment Patton's battlefield circulations. 
operational environment, and created a solid foundation for Seventh Army planners to create their operational plan. ${ }^{85}$

Given Koch's timely intelligence estimate Patton convened a planning session on 5 May with several of his key leaders including: Major General Geoffrey Keyes, his deputy commanding general, Brigadier General Maxwell Taylor of the $82^{\text {nd }}$ Airborne division, and Major General Ernst Dawley, Commander of VI Corps, later switched to Bradley's II Corps on Patton request. Patton's objective was to develop a concept for the American landing based on the latest HUSKY plan to facilitate detailed planning in coordination with Force 141. In his initial concept Patton envisioned the $45^{\text {th }}$ Infantry Division landing at Scoglitti, the $1^{\text {st }}$ Infantry Division at Gela, $3^{\text {rd }}$ Infantry Division at Licata, with the $2^{\text {nd }}$ Armored Division task organized with each landing force, and the $82^{\text {nd }}$ Airborne Division landing behind the beaches to reinforce. Keyes recommended a reserve consisting of two regimental combat teams from the $1^{\text {st }}$ Infantry Division and one combat command from the $2^{\text {nd }}$ Armored Division, which Patton accepted. The entire meeting took place in about one hour. Patton later wrote in his diary, "someday bemused students will try to see how we came to this decision and credit us with profound thought we never had," downplaying his contribution to planning ${ }^{86}$ His critics after the war, including Bradley, would fault Patton for his lack of concern for details in planning. To the contrary, Patton understood his role as an army commander to provide clear and concise guidance to enable his staff and subordinate units to conduct detailed planning. Carlo D'Este, author of Patton: A Genius for War, corroborates this point: "Patton's important contribution to planning of the invasion was that he articulated a relatively uncomplicated, straightforward concept of the operation, and left his staff

\footnotetext{
${ }^{85}$ Koch and Hays, G-2: Intelligence for Patton, 47-48.

${ }^{86}$ Blumenson, The Patton Papers: 1940-1945, 241.
} 
to work out the details. ${ }^{" 87}$ In short, Patton's conduct in planning epitomized the concept of mission command prevalent in current U.S Army doctrine. ${ }^{88}$

On 7 May Patton sent Keyes along with Lieutenant Colonel Paul D. Harkins, Seventh Army Deputy Chief of Staff, and Colonel Walter J, Muller, the logistics officer (G-4) to Algiers to coordinate the Seventh Army concept with planners from Montgomery's Eighth Army and Force 141. Patton directed his staff in their parallel planning and personally consulted with Alexander concerning the necessity of establishing a boundary between the British and American forces. Moreover, he implored Alexander to create phase lines to outline initial objectives for the American and British landings, but Alexander refused. Alexander's reluctance in establishing these simple graphic control measures represented yet another difference between the American and British understanding of planning.

American doctrine utilized phase lines as benchmarks to track the progress of offensive operations to facilitate command and control and predict sustainment requirements for units in battle. ${ }^{89}$ Conversely, the British did not believe in the utility of phase lines given the inability of planners to accurately predict unit progress against enemy forces in difficult terrain. Patton also attempted to cajole Alexander to direct his staff to develop and publish a general campaign plan that addressed operations beyond the landings, reminiscent of his early criticism of the HUSKY plan. Alexander would eventually establish a boundary between the Seventh and Eighth Armies

${ }^{87}$ D'Este, Patton: A Genius for War, 499.

${ }^{88}$ Ford, Assault on Sicily, 42. Major General Keyes supervised the detailed planning for HUSKY. Patton utilized the time to observe troop training and preparations for the invasion. In doing so Patton developed an understanding of the capabilities of his force. This understanding supported Patton's visualization for Sicily.

${ }^{89}$ United States War Department, FM 100-15 Field Service Regulations: Larger Units (Washington, DC: Government Printing Office, 1942), 96. States "phase lines are prescribed only when required to insure coordinated action or movement of two or more units." United States War Department, FM 17-10 Armored Force Field Manual (Washington, DC: Government Printing Office, 1942), 401. Defines phase lines as "a line or terrain feature which troops are directed to reach by a specified time, and which is utilized by a commander for control or coordination." 
starting at the coast near Pozzallo and proceeding north to the towns of Ragusa and Vizzini, but he never created a unified campaign plan for the invasion of Sicily. ${ }^{90}$ Later, the boundary would play an important role in Patton's visualization of ground operation in Sicily.

On 21 May Force 141, now incorporated as part of Alexander's 15 ${ }^{\text {th }}$ Army Group, issued the final operational plan for Sicily. Alexander's plan consisted of five phases: phase one begins with naval and air operations to neutralize Axis air capability; phase two comprised the amphibious and airborne assaults to capture critical airfields and the ports of Syracuse and Licata; phase three created a bridgehead to support offensive operations; phase four captured the ports of Augusta and Catania; and phase five, inadequately, called for the reduction of the island of Sicily. ${ }^{91}$ Within the higher unit's framework, Patton and the Seventh Army staff worked diligently to complete their plan. During this time period, Patton worked effectively with the naval commander of the Western Task Force, Navy Vice-Admiral Kent Hewitt. Patton and Hewitt had developed an effective relationship based on mutual respect from their service together during Operation TORCH. Patton understood that Hewitt went to great lengths to meet his planner's requests and trusted Hewitt when he stated something was not feasible. Patton best described naval preparation following the changes from HUSKY Eight in a letter to Marshall, "to save time and avoid complications in naval planning, we simply used our existing setup of sub task forces in the new locations." 92

Unfortunately, coordination with the Western Task Force air commander, Colonel T.J. Hickey, and Air Marshal Sir Arthur Coningham, commanding the North-West Tactical Air Force (NATAF), was less productive. The NATAF included the XII U.S. Air Support Command, led by

\footnotetext{
${ }^{90}$ Blumenson, The Patton Papers: 1940-1945, 244.

${ }^{91}$ Ford, Assault on Sicily, 40.

${ }^{92}$ Blumenson, The Patton Papers: 1940-1945, 246.
} 
Hickey, and provided direct support to the Seventh Army in Sicily. Throughout the planning process Seventh Army planners could never get air liaisons to coordinate the ground and air scheme of maneuver. In fact, it took the personal intervention of Major General Truscott, commanding the $3^{\text {rd }}$ Infantry Division, using his connections in the U.S. Army Air Corps to get air reconnaissance photos of his assigned landing beaches. ${ }^{93}$ The poor coordination between Patton and Hewitt with the Army Air Corps never improved. Patton, who understood the value of airpower in the combined arms team, loathed the laborious process used by air planners to resource missions that often took twelve to twenty-four hours to execute. ${ }^{94}$ Air support would remain one of Patton's greatest concerns as the Seventh Army finalized their plan for HUSKY.

The Western Task Force and Seventh Army completed their operational plan in June 1943. The Seventh Army objectives were the airfield at Ponte Olivio, Biscari, Comiso, and the small ports at Licata and Gela by D+2. Once secure, his force was to prepare for operations in support of the Eighth Army's left flank. Patton's analysis of the terrain in his area of operations illuminated the key terrain he would need to establish a bridgehead. To control this terrain, Patton created two phase lines as objectives for his landings. The first, the Yellow Line, ran from Palma di Montechiaro through Campobello, Mazzrino, Caltagirone, and Grammichele approximately twenty miles off the coast. The second phase line, the Blue Line, began at Campobello and traversed Piazza Armerina toVizzini along elevated terrain that overlooked lateral routes in the Seventh Army area of operations. From this location, Patton visualized advancing due north to

\footnotetext{
${ }^{93}$ Lucian K. Truscott, Jr., Command Missions: A Personal Story (New York: E.P. Dutton and Company, 1954), 200-201; Blackwell, Battle for Sicily, 64.

${ }^{94}$ Hirshson, A Soldier's Life, 355. Patton's experience from the Mexican Punitive Expedition detailed in section one provided him his first experience with reconnaissance aircraft.
} 
cut Sicily in half near the city of Enna. From Enna the Seventh Army would advance along the western side of Mt. Etna to Messina, the strategic objective of HUSKY. ${ }^{95}$

The final Seventh Army plan consisted of three simultaneous division-sized landings at Licata, Gela, and Scoglitti in the Bay of Gela. The $3^{\text {rd }}$ Infantry Division under Truscott, who had experience in amphibious operations from Operation TORCH, would land near Licata on JOSS Beach. The $3^{\text {rd }}$ Infantry Division's objectives included the port of Licata and a small airfield north of town by D+2, and then an advance to the Yellow Line objectives of Palma di Montechiaro, Campobello, and Mazzrino. The $3^{\text {rd }}$ Infantry Division would be under Patton's direct control. Bradley's II Corps included the $1^{\text {st }}$ Infantry Division, commanded by Major General Terry de la Mesa Allen, and the $45^{\text {th }}$ Infantry Division, under Major General Troy Middleton, coming straight from the United States for the operation. The $1^{\text {st }}$ Infantry Division would land on DIME Beach. Their objectives included the port of Gela and the Ponte Olivio airfield by D+1, followed by an advance to the Yellow Line. The $45^{\text {th }}$ Infantry Division was templated to land on CENT Beach and tasked with securing the airfields at Biscari and Comiso by nightfall of D+2. Following the seizure of Axis airfields, the division was to attack toward the Yellow Line. The $82^{\text {nd }}$ Airborne Division, commanded by Major General Matthew Ridgeway, was to conduct airborne insertions behind the beaches to control critical lateral routes and delay Axis counter-attacks. The Seventh Army reserve consisted of the $2^{\text {nd }}$ Armored Division led by Major General Hugh Gaffey and the $9^{\text {th }}$ Infantry Division commanded by Major General Manton Eddy (See Fig. 2). ${ }^{96}$

\footnotetext{
${ }^{95}$ Garland and Smyth, Sicily and the Surrender of Italy, 97-98; Blumenson, Patton, 194.

${ }^{96}$ Garland and Smyth, Sicily and the Surrender of Italy, 96-105; Staff of the Seventh Army, Report of the Operations of the US Seventh Army in the Sicilian Campaign, Part One-Summary of Operations, (Fort Leavenworth, KS: Combined Arms Research Library, August 2013), A-3-A-6; Headquarters, $45^{\text {th }}$ Infantry Division, Report of Operation of the $45^{\text {th }}$ Infantry Division in the Sicilian Campaign, 1 September 1943 (Fort Leavenworth, KS: Combined Arms Research Library, August 2013), 2; Headquarters, Third Infantry Division, Report of Operation, 10 September 1943 (Fort Leavenworth, KS: Combined Arms Research Library, August 2013), 4.
} 


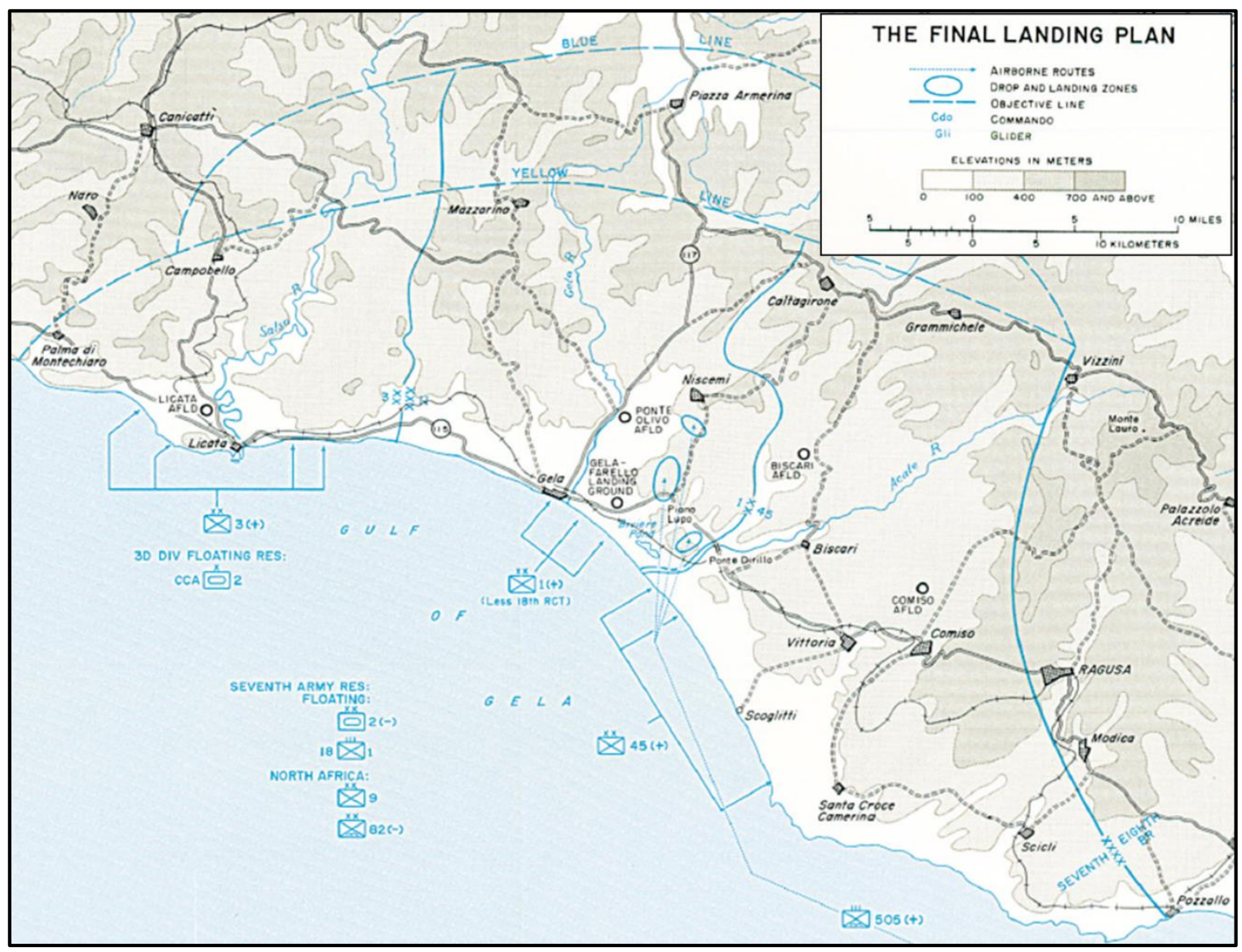

Figure 2. U.S. Seventh Army Final Landing Plan

Source: Garland and Smyth, Sicily and the Surrender of Italy, Map II.

On 21 June Eisenhower chaired a senior leader conference to present the final plan for Operation HUSKY. In his diary Patton graded the various speakers including Eisenhower, who he thought performed poorly during his ten minute introduction and stated that he is "acting like an associate rather than a commander." 97 The final brief of the day contained the Seventh Army plan. To conduct the briefing Patton, based on Keyes' suggestion, used the Army War College method to present the American operational plan. Patton began the brief with a six minute overview of the mission and general concept followed by his principle staff members providing a

\footnotetext{
${ }^{97}$ Blumenson, The Patton Papers: 1940-1945, 266.
} 
detailed description of each phase of the operation. The entire brief took twenty-two minutes, and Patton remarked in his diary later, "we stole the show." 98 When Patton overviewed the general plan for Seventh Army after the initial landings he described it as "a secure base line from which to undertake further operations for complete subjugation of the island as may be directed."99 This indicated that he was focused on the ground campaign, not just the landings like most of the other Allied leaders. One incident in particular, approximately a week prior to D-Day, supports the idea that Patton identified a potential branch plan to his visualized advance on Messina.

When Patton was traveling in and around Bizerte, Tunisia, he noticed a large shipment of trucks and jeeps inside a large compound. The compound belonged to Navy Captain William A. Sullivan, who befriended Patton at the Casablanca Conference. Sensing an opportunity, Patton dispatched a lieutenant colonel to obtain the vehicles. Sullivan's transportation officer informed him that the lieutenant colonel said he was to deliver the vehicles to Patton the next morning. Sullivan directed the officer to ignore the order and to not allow him back on the compound. That evening Sullivan discussed the incident with Patton, and this little known conversation recorded by Sullivan foreshadowed Patton's visualization of the coming campaign in Sicily and is worth quoting in full:

I [Sullivan] had just ordered my officer to kick the tail of one of his lieutenant colonels if he showed up in the morning, and tried to squeeze us out of our trucks. Patton laughed. He [Patton] said he himself was responsible for sending the officer around. He had seen our trucks driving around Bizerte. He said a certain son of a b-was trying to slow him up in Sicily, but when he hit Sicily he was going to go through that place like a dose of salts. He needed every truck he could get, steal or hijack. He knew I had no need of the trucks until we took Palermo. He would have to take Palermo before we could start working there. How about it? I had his word that I could have all the trucks I needed once we hit Palermo. ${ }^{100}$

\footnotetext{
${ }^{98}$ Blumenson, The Patton Papers: 1940-1945, 266.

${ }^{99}$ Ibid.

${ }^{100}$ Hirshson, A Soldier's Life, 361.
} 
This discourse between Patton and Sullivan just a week before the invasion of Sicily indicates that Patton visualized a potential advance on Palermo despite his mission to protect Montgomery's Eighth Army.

Patton understood that the operational objective required to meet the strategic aims laid out for HUSKY in Casablanca was Messina. Furthermore, he knew that time was of the essence if the Allies wanted to decisively defeat Axis forces defending Sicily, and that his forces would benefit from a major port like Palermo. Given his understanding of the requirements for operational success, and the Seventh Army need for a deep water port, it appears plausible that Patton visualized a Seventh Army advance on Messina prior to the invasion. To accomplish this task, Patton visualized either a direct approach from his beachhead, or an indirect approach following a branch plan to capture Palermo during the execution of the ground campaign.

\section{PATTON'S EXECUTION OF OPERATION HUSKY}

Patton boarded Admiral Hewitt's flagship the Monrovia during the morning of 6 July, 1943 to begin a three day voyage to posture the Western Task Force for its amphibious landings on the southern coast of Sicily on 10 July. During the approach, Patton continued to visualize how the campaign would unfold following the establishment of a beachhead. The purpose for Alexander's reluctance to develop a campaign plan beyond the lodgment eluded Patton, but would later provide an opportunity for him to expand the American role in Sicily. At midnight on 10 July, just hours before the invasion, Patton presided over a small ceremony on the Monrovia to officially activate the U.S. Seventh Army. In a short speech, Patton said, "this is the first army to be activated at midnight and baptized in blood before daylight." 101 The initiation of Seventh

\footnotetext{
${ }^{101}$ Farago, Patton: Ordeal an d Triumph, 290.
} 
Army's amphibious landings concluded seven months of planning and, for Patton, over thirtyfour years of personal and professional preparation. ${ }^{102}$

The study of Patton's development as an operational artist during the execution of Operation HUSKY will focus on three critical events during the campaign. The first critical event is the amphibious landings and the establishment of a foothold in Sicily. The second event concerns the boundary dispute between the American and British Army's resulting in the trigger that would prompt Patton to execute his visualized branch plan to Palermo. The last critical event includes the final advance on Messina, followed by lessons learned and Patton's operational art from Sicily.

\section{The Seventh Army Landings}

Operation HUSKY began in the early hours of 10 July 1943 with H-Hour set for 0245

hours. Patton had moved to the deck of the Monrovia at 0200 hours to observe landing craft make their way to their assigned beaches as naval gun fire silenced Italian coastal batteries and remarked, "we may feel anxious but I trust the Italians are scared to death." 103 At H-Hour heavy seas hampered the Navy's efforts to deliver assault forces to the appropriate beaches resulting in many delays especially for the $45^{\text {th }}$ Infantry Division at Scoglitti. Earlier, the same weather created forty knot head-winds for the inexperienced pilots attempting to deliver elements of the 82nd Airborne Division to their drop zones on elevated terrain northeast of Gela near the Ponte Olivio airfield. The high winds scattered the paratroopers across southeastern Sicily and only a few managed to reach their assigned objectives. ${ }^{104}$

\footnotetext{
${ }^{102}$ Blumenson, Patton, 195.

${ }^{103}$ Blumenson, The Patton Papers: 1940-1945, 275.

${ }^{104}$ Staff of the Seventh Army, Report of Operations, B-6.
} 
Despite the weather, the Seventh Army landings generally went according to plan.

Truscott's 3rd Infantry Division, largely operating independently as the JOSS Force, landed to the east and west of the city of Licata to position his forces for a double envelopment. Truscott's men encountered light opposition from the Italian $207^{\text {th }}$ Coastal Division and the city fell quickly. In seven hours the well-trained $3^{\text {rd }}$ Infantry Division had secured their D-Day objectives, the port at Licata and an airfield north of town, and sent patrols toward Palma di Montechiaro and Campobello along the Yellow Line. ${ }^{105}$

While the $3^{\text {rd }}$ Infantry Division secured the Seventh Army's left flank, Middleton's $45^{\text {th }}$ Infantry Division attempted to anchor the right flank at Scoglitti. The $45^{\text {th }}$ Infantry Division landed on two beaches eight miles apart on both sides of the small fishing village of Scoglitti against light enemy resistance. Despite considerable confusion on the beach from heavy seas, piecemeal landings, and the division's inexperience they methodically moved inland seven miles to establish a beachhead by the end of D-Day. ${ }^{106}$ The final and most contested of the Seventh Army landings occurred at Gela by Allen's veteran $1^{\text {st }}$ Infantry Division.

Patton had personally selected the $1^{\text {st }}$ Infantry Division for the landing at Gela based on his prediction that Gela would offer the most significant resistance on D-Day, and his intuition proved correct. The $1^{\text {st }}$ Infantry Division landings on the DIME Beaches encountered moderate resistance from Italian machine gun positions and by 0800 hours had captured the town of Gela. As elements of the $1^{\text {st }}$ Infantry Division established a hasty defense to the north and east of Gela in preparation for Axis counterattacks, the rest of the division moved slowly inland to link-up with American paratroopers. In response, elements of the German Hermann Goring Division and

${ }^{105}$ H. Paul Jeffers, Command of Honor: General Lucian Truscott's Path to Victory in World War II (New York: Penguin Group, 2008), 118. The $3^{\text {rd }}$ Infantry Division landed on JOSS Beach, and they operated independently, which led to the name JOSS Force.

${ }^{106}$ D’Este, Bitter Victory, 261-265. 
the Italian Livorno Division executed determined, but uncoordinated, counterattacks against the Gela Landings. With the aid of naval gunfire Allen's $1^{\text {st }}$ Infantry Division repulsed the counterattacks and consolidated their beachhead as D-Day concluded on $10 \mathrm{July} .{ }^{107}$ Anticipating further attacks at Gela, Patton ordered Gaffey's $2^{\text {nd }}$ Armored Division, part of his floating reserve, to disembark at Gela in support of the $1^{\text {st }}$ Infantry Division. Once again Patton's ability to visualize the actions of his enemies would prove correct (See Fig. 3). ${ }^{108}$

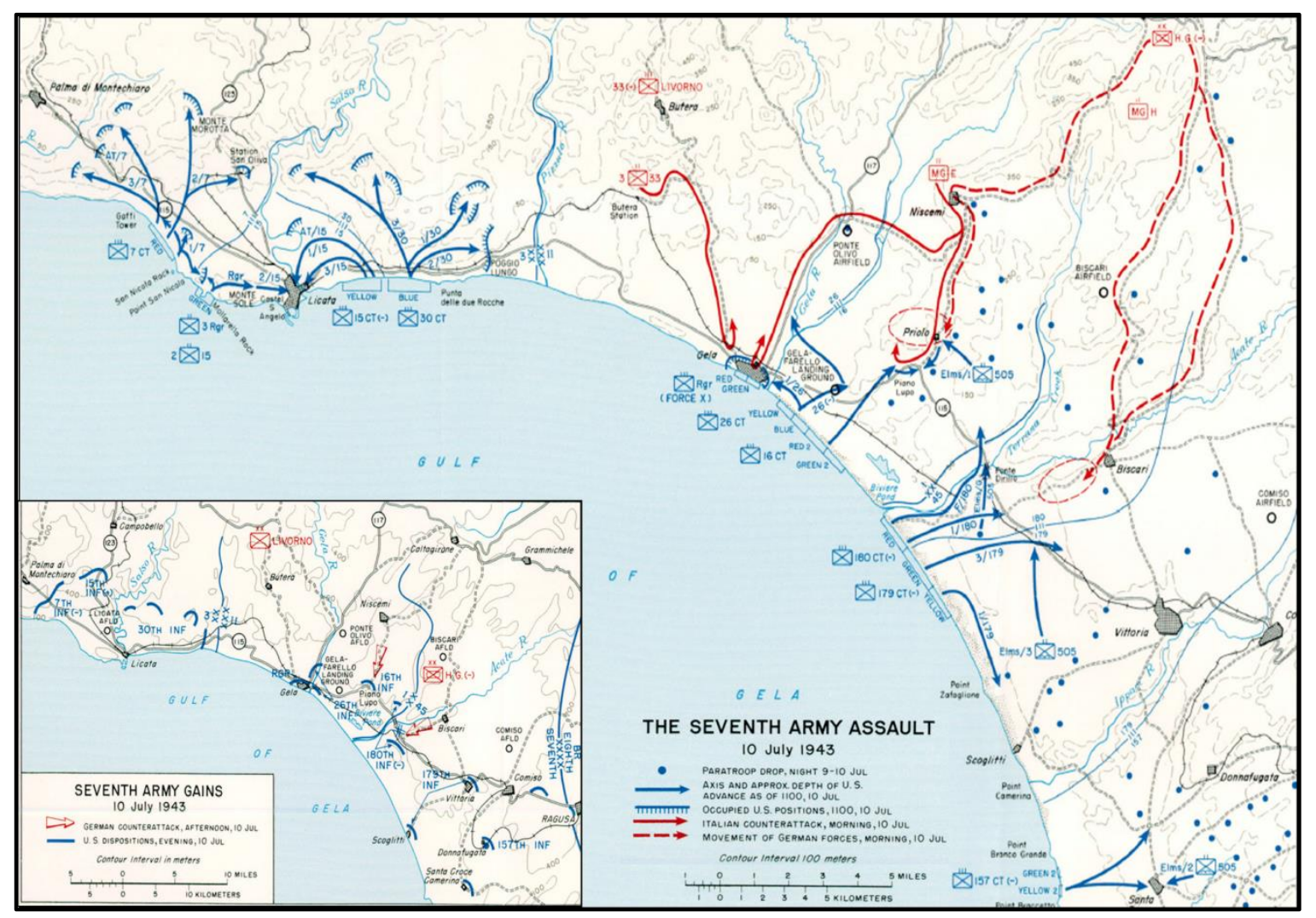

Figure 3. U.S. Seventh Army Assault of Sicily

Source: Garland and Smyth, Sicily and the Surrender of Italy, Map III.

${ }^{107}$ Ford, Assault on Sicily, 103-109.

${ }^{108}$ Headquarters, $2^{\text {nd }}$ Armored Division, Historical Record: Operations of US Second Armored Division, 5 August 1943 (Fort Leavenworth, KS: Combined Arms Research Library, August 2013), 5. 
The British D-Day landings met less resistance than the Americans and seized their initial objectives on schedule including the city of Syracuse. However, when Montgomery's forces proceeded to Augusta a hastily established German defense stopped the British advance, but this was only the beginning of the problems facing the British Eighth Army in Sicily. Throughout DDay Patton remained on the Monrovia believing that he would only complicate actions ashore with his presence. By D+1 Patton could wait no longer and went ashore near Gela at 0930 hours with a small staff element.

Patton moved to Lieutenant Colonel William O. Darby's command post in the town of Gela. Darby commanded two Ranger battalions designated Force X and task organized to Allen's $1^{\text {st }}$ Infantry Division for the invasion. Upon his arrival the second Axis counterattack began, and Patton observed the action from an observation post. There he personally ordered a Navy officer to use his radio for fire support against the attacking Italians, and then contacted Gaffey, the $2^{\text {nd }}$ Armored Division Commander, in the process of disembarkation to "close the gap between Gela and the $1^{\text {st }}$ Division and send a company of tanks to help Darby." ${ }^{109}$ This support allowed Darby to counterattack and defeat the Italian assault on Gela. Patton continued his battlefield circulation to the $1^{\text {st }}$ Infantry Division command post.

In a conversation with Allen Patton inquired about the status of his division, and Allen responded that he was holding, but needed additional artillery support. In contrast to his personal interference at Gela Patton stated, "I'm now an army commander; take it up with Bradley." He then proceeded to admonish Allen for failing to seize Ponte Olivio airfield yet, an objective scheduled for D+1, and departed. ${ }^{110}$ Patton did, however, interfere with Bradley's operations

\footnotetext{
${ }^{109}$ George S. Patton, War As I Knew It (New York, Houghton Mifflin, 1947), 55.

${ }^{110}$ Gerald Astor, Terrible Terry Allen: Combat General of World War II-The Life of an American Soldier (New York, Random House Publishing, 2003), 199; Harold R. Winton Corps Commanders of the Bulge: Six American Generals and Victory in the Ardennes (Lawrence, Kansas: University Press of Kansas, 2007) 2. Winton described the role of a field army commander to provide administrative and logistical
} 
when he annulled one of his orders to Allen beginning the deterioration of Patton and Bradley's relationship. ${ }^{111}$ Following the repulse of the Axis counterattacks, Patton returned to the Monrovia around 1900 hours that evening and stated in his diary, "this is the first day of the campaign that I think I earned my pay."112

There are valuable lessons for the student of operational art during Patton's first day in action on Sicily. Patton's presence received varied reviews beginning with Major General John Lucas, Eisenhower's deputy commander, who described Patton's performance during the Axis counterattacks, "General Patton was ashore at the time, and I am convinced that his presence had much to do with restoring the situation." ${ }^{113}$ Conversely, the scholar Carlo D' Este believes that Patton's presence had no effect on the successful American defense, and his battlefield circulations during the course of the campaign had diverse effects on troop morale. ${ }^{114}$ Patton also had mixed reviews in the execution of mission command when he personally intervened in the affairs of his tactical commanders, while he simultaneously trusted his deputy commander Major General Keyes to oversee the progress of the entire battle. However, as the army commander Patton ensured he was at the decisive point during a critical time to positively influence the outcome.

In reality, Patton's greatest contribution to the Seventh Army defense occurred months earlier during the planning for Sicily when he advocated for the inclusion of the $1^{\text {st }}$ Infantry

support to corps. Corps provided tactical direction to supporting divisions, and other combat support assets. Patton as a new field army commader had much to learn about his role and his relationship with his subordinate commanders.

${ }^{111}$ D'Este, Patton: A Genius for War, 507. While Patton provided a great example of mission command during the planning of Operation HUSKY, during the execution his implementation of mission command was inconsistent.

${ }^{112}$ Patton, War As I Knew It, 57.

${ }^{113}$ Blumenson, The Patton Papers: 1940-1945, 278.

${ }^{114}$ D’Este, Bitter Victory, 301. 
Division to the American order of battle. Bradley with rare praise stated, "Patton had prevailed on Eisenhower to substitute the veteran $1^{\text {st }}$ Infantry Division for the $36^{\text {th }}$ Infantry Division (an untested division) on this invasion. In doing so he may have saved II Corps from a major disaster." 115 Furthermore, Patton's understanding of the enemy, terrain, and his own forces predicated the placement of $1^{\text {st }}$ Infantry Division at Gela and the employment of elements of his floating reserve. Arguably one area Patton failed to enable his forces was in close air support. Patton departed for the invasion uncomfortable with the integration of air and ground efforts, but he failed to push the issue and a significant number of sorties on 11 July were dedicated to air interdiction missions rather than close air support. As a result, Allied airpower had little effect on Axis counterattack forces, and the $1^{\text {st }}$ Infantry Division was reliant on naval gunfire on $11 \mathrm{July} .{ }^{116}$

The Boundary Dispute and Palermo

As the conclusion of 11 July approached Patton was satisfied with his army's progress on $\mathrm{D}+1$. In addition to Allen's successful defense of the Gela beachhead, Truscott's $3^{\text {rd }}$ Infantry Division had advanced to the Yellow Line at Palma di Montechiaro and Campobello. The $45^{\text {th }}$ Infantry Division secured the Comiso Airfield and the town of Ragusa anchoring the Seventh Army's right flank on the boundary with Montgomery's British Eighth Army. However, before the day ended, one tragedy occurred that partially nullified much of the army's progress. ${ }^{117}$

The original Seventh Army plan for HUSKY called for an airborne insertion of the remainder of the $82^{\text {nd }}$ Airborne Division behind the Seventh Army's forward line of troops near

\footnotetext{
${ }^{115}$ Bradley, A Soldier's Story, 130; Carl Von Clausewitz, On War (Princeton, NJ: Princeton University Press, 1976), 102; Nye, The Patton Mind, 72. Refers to how Patton read Carl Von Clausewitz in 1926, and how he underlined the section on coup d'oeil (visualization) that talks of a commander's "inward eye."

${ }^{116}$ D’Este, Bitter Victory, 305.

${ }^{117}$ Staff of the Seventh Army, Report of Operations, B-6.
} 
Gela. At the front Patton observed that anti-aircraft crews were rather jumpy due to continuous Axis air attacks throughout the day, and he attempted to stop the air insertion. Unfortunately it was too late, and Patton voiced his concern in his diary that evening. ${ }^{118}$ Just prior to the $82^{\text {nd }}$ Airborne drop, German planes attacked the fleet and predictably anti-aircraft crews were on high alert when the friendly transports approached. The resulting friendly fire incident cost the $82^{\text {nd }}$ Airborne 229 casualties. ${ }^{119}$ On 12 July Eisenhower visited Patton's headquarters aboard the Monrovia for an operations update, but instead he proceeded to admonish Patton concerning inadequate reporting. The next day Eisenhower learned of the friendly fire incident and sent Patton a cable demanding an investigation and implied the incident was his fault. The negative encounters with Eisenhower incited Patton's belief that he may be relieved, and left him surprisingly impotent for the coming boundary dispute with Montgomery's Eighth Army. ${ }^{120}$

From 12-13 July the Seventh Army continued to expand its foothold in Sicily capturing the Ponte Olivio airfield and defeated a German counterattack at Nisemi. Seventh Army Field Order Number One issued on 13 July directed the major subordinate commands to expand their foothold to the Yellow Line and push Axis artillery beyond the range of their captured airfields. ${ }^{121}$ At the same time Montgomery and his Eighth Army struggled to penetrate the German lines into the Catania Plain. To break the deadlock, Montgomery without permission postured his army to advance around the west side of Mt. Etna using Highway 124 in Seventh Army's area of operations to create a second axis of advance to Messina. Concurrently, elements

\footnotetext{
${ }^{118}$ Blumenson, The Patton Papers: 1940-1945, 280. Based on his observations, Patton predicted that the air insertion had a high risk of fratucide. He sent a message directing all of his subordinates to notify their units of the $82^{\text {nd }}$ Airborne Division drop. However, he still felt the message may have not been disseminated effectively. Patton noted in his diary that evening, "am terribly worried."

${ }^{119}$ Garland and Smyth, Sicily and the Surrender of Italy, 175-182.

${ }^{120}$ D'Este, Patton: A Genius for War, 511.

${ }^{121}$ Staff of the Seventh Army, Report of Operations, B-6.
} 
of Middleton's $45^{\text {th }}$ Division advanced north to seize the section of Highway 124 west of Vizzini and reported that British forces were also advancing on Vizzini. ${ }^{122}$

Alexander visited the Seventh Army headquarters the morning of 13 July prior to giving approval for Montgomery's actions along Highway 124. During the meeting Patton requested permission to seize Agrigento and Porto Empedocle to secure the port for logistical support. Alexander agreed, but constrained Patton to the use of limited forces, and then directed him to avoid a major engagement and reminded him of his mission to protect the Eighth Army's flank. ${ }^{123}$ Alexander, however, never mentioned Montgomery's request for Highway 124. Prior to midnight on 13 July Alexander sent a directive to Patton's headquarters giving the Eighth Army control of Highway 124 . The directive effectively denied the Americans the possibility of a northern advance west of Mt. Etna, and confirmed the Seventh Army's limited role in the campaign. ${ }^{124}$

Before the invasion Patton had visualized a potential Seventh Army advance on Messina around the western side of Mt. Etna, and Highway 124 made this action possible. However, Patton did not protest the loss of Highway 124 and he immediately ordered Bradley to shift his forces west, but why? One possible reason is that Patton thought Eisenhower might relieve him if he protested, but his actions following the directive indicate that he simply made the decision to execute his branch plan to western Sicily. Patton's subtle inquiry before the invasion concerning the use of Captain Sullivan's vehicles in Bizerte was the first indicator, but his request to seize Agrigento and Porto Empedocle was the second. While this location did contain a small port to augment his logistical capacity, it also postured his army on the two parallel routes to Palermo. In

\footnotetext{
${ }^{122}$ Garland and Smyth, Sicily and the Surrender of Italy, 206-209.

${ }^{123}$ Blumenson, The Patton Papers: 1940-1945, 285.

${ }^{124}$ Garland and Smyth, Sicily and the Surrender of Italy, 206-209.
} 
essence, the road network in Agrigento and Porto Empedocle was key terrain for Patton and provided him the option of using his indirect approach to Messina.

Patton wasted no time and issued an addition to Field Order Number One following his meeting with Alexander directing Truscott's $3^{\text {rd }}$ Infantry Division to conduct a reconnaissance to Agrigento and to control the key road juncture at Canicatti. On 14 July Patton visited Truscott to discuss the operation to Agrigento and Porto Empedocle. Patton told Truscott, "the army would need the port of Porto Empedocle for the drive on Palermo," but acknowledged that he had no order to attack Agrigento. ${ }^{125}$ Truscott understood Patton's intentions and prepared to conduct a reconnaissance in force to seize the limited objective of Agrigento as a prerequisite for further operations in western Sicily. ${ }^{126}$

Patton continued to set the conditions for his branch plan on 15 July when he formed a Provisional Corps consisting of the $3^{\text {rd }}$ Infantry Division, $82^{\text {nd }}$ Airborne Division, elements of the $9^{\text {th }}$ Infantry Division, and later the 2nd Armored Division under the command of his deputy commander Major General Keyes. ${ }^{127}$ He also consulted with his G2, Colonel Oscar Koch, about the enemy in Agrigento to ensure he complied with Alexander's guidance to not start a major engagement. Koch assessed light enemy resistance, and requested guidance on where to employ a recently arrived detachment from the Office of Strategic Services (OSS). Patton directed them to infiltrate the Palermo area further indicating his intention to seize Palermo. ${ }^{128}$ By 16 July the $3^{\text {rd }}$ Infantry Division had completely enveloped Agrigento and seized Porto Empedocle, while the

${ }^{125}$ Truscott, Command Missions, 218.

${ }^{126}$ United States War Department, FM 100-5: Field Service Regulations: Operations (Washington, DC: Department of the Army, May 1941). States a reconnaissance in force constitutes the best means of clearing up an uncertain situation. Troops engaged in a reconnaissance in force usually make a local attack with a limited objective.

${ }^{127}$ Staff of the Seventh Army, Report of Operations, B-8.

${ }^{128}$ Robert Hays, Patton's Oracle: Gen. Oscar Koch, as I Knew Him (Savoy, IL: Lucidus Books, 2013), 110. 
Provisional Corps repositioned in preparation for an advance west. With the conditions nearly set for an advance on Palermo there was only one task left, ask Alexander for permission. ${ }^{129}$

On 16 July Alexander issued a new directive to his army commanders to force the enemy into the Messina Peninsula. The new directive, similar to the 13 July directive, ordered Montgomery's Eighth Army to attack Messina using three axes, one to the east of Mt. Etna and the other two west of Mt. Etna to converge on Messina. The Seventh Army had only one task, protect the flank and rear of the Eighth Army. ${ }^{130}$ Angered by the directive, Patton flew to Alexander's headquarters in Tunis on 17 July to present his alternate plan for the envelopment of Palermo as the best method to protect Montgomery's flank. Alexander agreed to Patton's plan. The Seventh Army's subsequent maneuver to Palermo would validate Patton's assessment of the operational environment. ${ }^{131}$

Patton issued his plan for the offensive on 18 July following his army's final preparations, which included the establishment of a logistical base at Porto Empedocle and the consolidation of the Provisional Corps at Agrigento. The plan called for Bradley's II Corps to secure the British Eighth Army rear near Enna, and advance northwest to envelope Palermo from the east. Concurrently, Keyes' Provisional Corps, the main effort, would advance on Palermo from the south and southwest. The $2^{\text {nd }}$ Armored Division as the army reserve would be prepared

\footnotetext{
${ }^{129}$ Staff of the Seventh Army, Report of Operations, B-9.

${ }^{130}$ Staff of the Seventh Army, Report of the Operations, Part Two-Staff Section Reports, G3 Report, D-9.

${ }^{131}$ Blumenson, The Patton Papers: 1940-1945, 290. Patton stated in his diary "I am sure that neither he [Alexander] nor any of his British staff had any conception of the power and mobility of the Seventh Army."
} 
to exploit a breakthrough, or extend the envelopment of Palermo to the west. The final assault on Palermo would be coordinated by Seventh Army headquarters once all units were in position. ${ }^{132}$

The offensive to Palermo began on 19 July led by Truscott's $3^{\text {rd }}$ Infantry Division, which was known for their high rate of march nicknamed the "Truscott Trot." ${ }^{133}$ Truscott's men traversed one hundred miles in seventy-two hours through mountainous terrain to seize the town of Corleone south of Palermo. The $82^{\text {nd }}$ Airborne advanced simultaneously to Costelvetrano to protect the Seventh Army's left flank and set the conditions for the final assault on Palermo. The Provisional Corps' rapid advance, and light Italian resistance, prompted Patton on 21 July to provide Keyes with the $2^{\text {nd }}$ Armored Division to increase the tempo of the operation. The final assault on Palermo began on 22 July when the 2 nd Armored Division and $3^{\text {rd }}$ Infantry Division executed a double envelopment of Palermo resulting in the city's surrender that evening achieving the decisive point for Seventh Army's operation in Sicily (See Fig. 4). During the final attack toward Palermo the $2^{\text {nd }}$ Armored Division covered sixty miles in approximately ten hours using combined arms teams of tanks and infantry to quickly clear roadblocks exemplifying Patton's guidance for continuous attack. Concurrently, Bradley's II Corps advanced north to his objectives where he met stiffer resistance, but he succeeded in cutting the road on the north coast of Sicily connecting Palermo to Messina. ${ }^{134}$

\footnotetext{
${ }^{132}$ Staff of the Seventh Army, Report of Operations, D-11. The logistical base at Porto Empedocle was vital to Patton's branch plan to Palermo because it permitted him to extend his operational reach. Looking back to section one, Patton first learned about operational reach during his time commanding a tank brigade in World War One. Patton needed to consider the capabilities of his force to extend their operations from the southern shore of Sicily to Palermo without losing the capacity to continue offensive operations.

${ }^{133}$ D’Este, Patton: A Genius for War, 519.

${ }^{134}$ Staff of the Seventh Army, Report of Operations, B-9-B-10; Headquarters, $2^{\text {nd }}$ Armored Division, Historical Record, 8-11.
} 


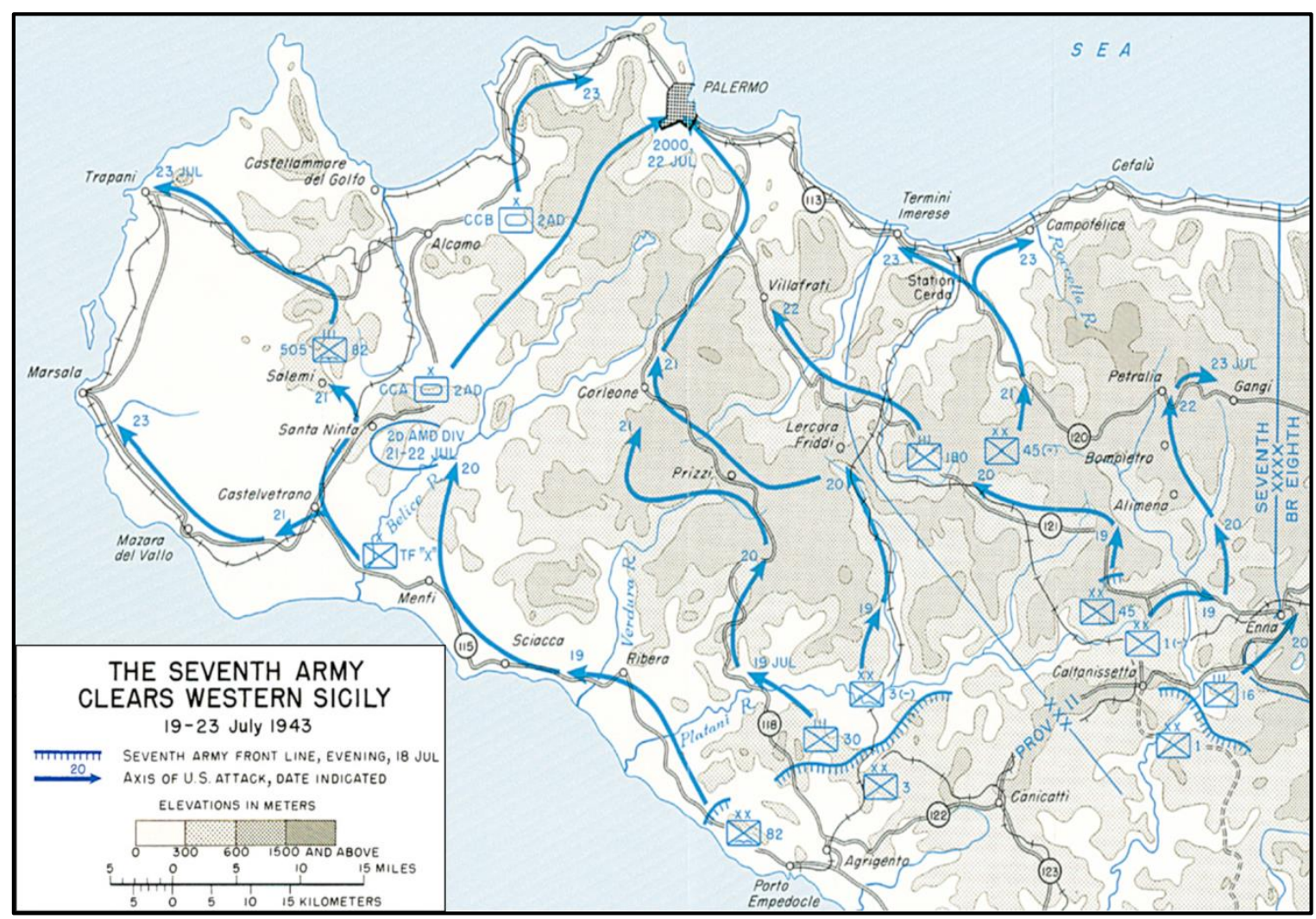

Figure 4. The U.S Seventh Army Clears Western Sicily

Source: Garland and Smyth, Sicily and the Surrender of Italy, Map VII.

Patton's offensive to Palermo resulted in the capture of a major port, 53,000 captured Italian troops, 2,900 enemy killed and wounded with only 272 casualties for the Provisional Corps in just five days. ${ }^{135}$ Patton's planning and conduct during the offensive elucidates his maturation as an operational artist. His ability to visualize the need for a branch plan to Palermo to reach his ultimate goal of Messina allowed him to arrange his forces in time and space to rapidly achieve the decisive point of the Sicilian Campaign. The capture of Palermo was decisive, not because of the physical damage caused to Axis forces, but because it effectively cut the island of Sicily in two and postured Patton's force on a direct route to Messina.

${ }^{135}$ Garland and Smyth, Sicily and the Surrender of Italy, 255. 
Capitalizing on years of professional experience with mechanized forces from the First World War to his most recent experience in Tunisia, Patton developed an innate understanding of tempo in combined arms operations. Patton surmised that his method of attacking constantly was superior to the British system of methodically stopping to build up, which he felt robbed the British of the initiative. Put simply, Patton stated "my policy of continuous attack is correct," and he would maintain this philosophy during future operations commanding the Third Army. ${ }^{136}$ Another consideration of Patton's operational art is his ability to accurately estimate his operational reach. Operational reach enables the sustainment required for tempo, while a sustainable tempo extends operational reach. ${ }^{137}$ Patton displayed that he understood their intrinsic relationship when he established the seizure of Porto Empedocle as a required condition before commencing the offensive to Palermo. Additionally, Patton immediately coordinated the regeneration of port capacity on Palermo to facilitate the next phase of the operation, the advance on Messina. ${ }^{138}$

\section{$\underline{\text { Advance on Messina }}$}

As the Seventh Army captured Palermo and cleared the remainder of western Sicily of Axis forces, Montgomery's Eighth Army continued to struggle against an increasingly wellorganized German defense in eastern Sicily. In preparation for an advance on Messina, Bradley's II Corps began to attack eastward on two axes with the $45^{\text {th }}$ Infantry Division traveling Highway 113 on the north coast road and the $1^{\text {st }}$ Infantry Division on Highway 120 twenty miles inland. To enable II Corps, Patton augmented it with additional artillery from the Provisional Corps as it

\footnotetext{
${ }^{136}$ Blumenson, The Patton Papers: 1940-1945, 293-294.

${ }^{137}$ Headquarters, Department of the Army, ADRP 3-0, 4-5.

${ }^{138}$ Garland and Smyth, Sicily and the Surrender of Italy, 256.
} 
began to meet a skillful German defense in constrictive terrain, and called forward Major General Manton S. Eddy's $9^{\text {th }}$ Infantry Division. ${ }^{139}$

On 25 July Montgomery invited Patton to a commander's conference in Syracuse to discuss future operations. During the meeting, Montgomery agreed to Patton's requirement for the continued use of Highways 113 and 120, and suggested Patton lead the Allied effort to seize Messina. Alexander arrived during the meeting, and was noticeably angry that Patton and Montgomery had formulated the plan without him. After forcing his army commanders to back brief their plans in a vain effort to exert control over the situation, Alexander approved the proposal. Due to the boundary dispute, and Montgomery's disregard for the Americans, Patton was rightfully suspicious of Montgomery's intentions, and thus considered the advance on Messina a race for national prestige. Montgomery, however, did not share this view and simply understood that success in Sicily required a coordinated effort between the Seventh and Eighth Armies. ${ }^{140}$

The Allies' new plan for the reduction of the Messina Peninsula elevated the role of Seventh Army and, following his successful branch plan to Palermo, placed Patton on a direct route to his original objective of Messina. However, Patton remained mistrustful of his British allies, which had negative implications on his execution of mission command. His mistrust resulted in an unnecessary obsession to reach Messina before the British that facilitated intermittent interference with his subordinates' operations during the last two weeks of the campaign. As July 1943 drew to a close, the II Corps advance east encountered increasingly stubborn German resistance from the newly arrived $29^{\text {th }}$ Panzer Grenadier Division on the coastal road and the $15^{\text {th }}$ Panzer Division along Highway 120 . The Germans advantageously used the

\footnotetext{
${ }^{139}$ Staff of the Seventh Army, Report of Operations, B-10-B-12.

${ }^{140}$ Ford, Assault on Sicily, 202-203.
} 
restrictive terrain of Sicily to execute successful rearguard actions to enable Axis forces to establish a defensive line across the Messina Peninsula called the Etna Line (See Fig. 5). ${ }^{141}$

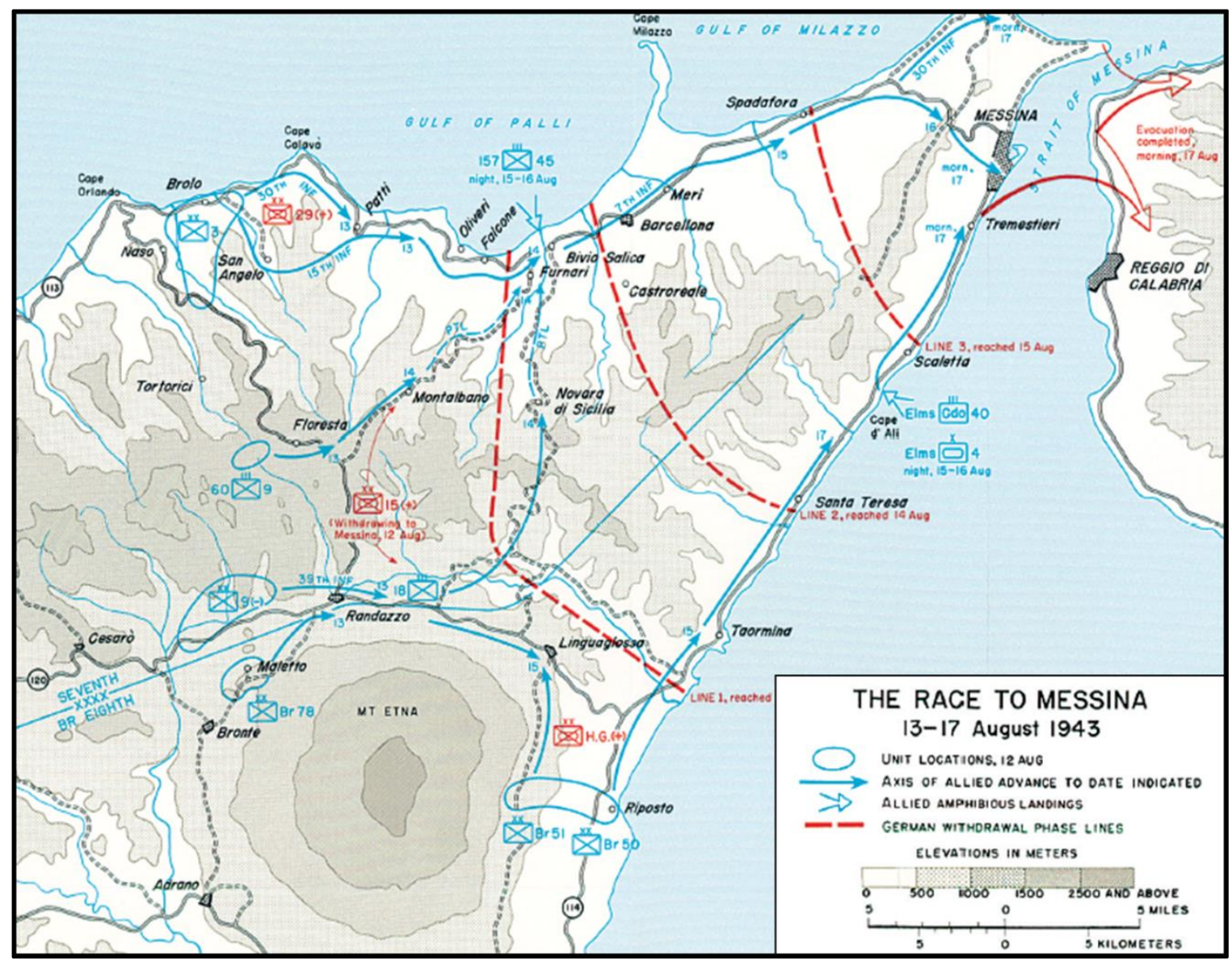

Figure 5. U.S. Seventh Army Race to Messina

Source: Garland and Smyth, Sicily and the Surrender of Italy, Map VIII.

Following intense fighting on the northern coastal road, Patton made the decision to relieve Middleton's exhausted $45^{\text {th }}$ Infantry Division with Truscott's better-rested $3^{\text {rd }}$ Infantry Division. Patton's decision indicated that he planned to increase the tempo of his operations, not only because Truscott's men had a reputation for aggressiveness and rapid forced marches, but

${ }^{141}$ Staff of the Seventh Army, Report of Operations, B-12-B-15. 
they were the most proficient at amphibious landings. This suggested that Patton was considering using the sea to out-flank German defenses given the fact his divisions were separated by mountains and incapable of providing mutual support. Patton understood that to penetrate the German Etna line he needed to seize two locations: Mt. San Fratello, which commanded the coastal route, and the mountain town of Troina located along Highway 120. In arguably the hardest battle of the campaign, the $1^{\text {st }}$ Infantry Division ended a week long battle to seize Troina on 6 August 1943, while the $3^{\text {rd }}$ Infantry struggled to penetrate the German line at Mt. San Fratello. To break the German defense, Bradley and Truscott conceived a plan for an amphibious envelopment of the German position at Mt. San Fratello with a simultaneous ground attack by all three of Truscott's infantry regiments. After a fierce fight, the operations succeeded in breaking the German line and the Germans retreated to a new defensive line. ${ }^{142}$

The success of the first amphibious envelopment led Patton to order Bradley to conduct another amphibious landing at Brolo to break the German line at Cape Orlando. Bradley and Truscott worked to set the conditions for the planned attack on 10 August, but a German air attack on landing craft supporting the operation forced a one day delay. In addition, they were unable to posture the supporting artillery and ground element in time. Truscott requested to postpone the operation and Bradley agreed but Patton, frustrated with his perception of slow progress to Messina, demanded the operation commence on 11 August. As result of Patton's interference and willingness to accept unnecessary risk, the amphibious operation failed to achieve the desired results of cutting the German line of retreat. The uncoordinated effort incurred high casualties and irrevocably eroded the trust between Patton and Bradley, a vital component of mission command. ${ }^{143}$

\footnotetext{
${ }^{142}$ D'Este, Bitter Victory, 305.

${ }^{143}$ Hirshson, A Soldier's Life, 390-392.
} 
Patton's incessant demand on his subordinates to increase their tempo to Messina encouraged him to demand a third amphibious landing, but this time with an entire regiment from the $45^{\text {th }}$ Infantry Division on 16 August. Truscott insisted that his force would progress beyond the templated landing site rendering the action irrelevant, but it was decided not to address the issue with Patton based on his reaction to the recommended delay at Brolo. The operation occurred as planned and Truscott's staff met the landing force on the beach. ${ }^{144}$ At this point it was clear that Patton's one man race with the British had negatively influenced his decision making skills that served him so well earlier in the campaign. The lead elements of the $3^{\text {rd }}$ Infantry Division entered Messina during the evening of 16 August and the city officially surrendered to Patton on 17 August ending the thirty-eight day campaign in Sicily.

Lessons Learned and Sicily's Influence on Patton's Operational Art

During the reduction of the Messina Peninsula the Germans, and later Italians, executed a successful operation to evacuate the majority of their forces across the Strait of Messina as the Allies advanced on Messina. The Allies failed to recognize the German withdrawal until it was nearly too late to interdict, and the lack of coordination among the senior ground, air, and naval commanders for Operation HUSKY prevented them from delivering the effects required to block the Strait of Messina. As a result, many historians consider the victory in Messina a hollow one because it failed to destroy the Axis forces on Sicily. ${ }^{145}$

In this perceived failure, Alexander incurs the majority of the blame because he failed to coordinate the larger Allied effort to deny the Germans access to the Strait of Messina.

Furthermore, he never developed a unified campaign plan for the ground forces in Sicily, which resulted in a lack of synchronization between British and American forces. While the Allied

${ }^{144}$ D’Este, Patton: A Genius for War, 529.

${ }^{145}$ D’Este, Bitter Victory; Mitchum and Stauffenberg, The Battle of Sicily are two authors that represent the view that the Allied victory in Sicily was incomplete. 
forces in Sicily did miss an opportunity to decisively defeat the Axis force in Sicily, it is irrelevant to the overall success of Operation HUSKY. The total destruction of Axis forces in Sicily was never one of the original strategic aims for Operation HUSKY. As a reminder, the strategic aims for Operation HUSKY included: the occupation of Sicily to make Mediterranean lines of communication more secure, divert German pressure from the Eastern Front, intensify pressure on Italy, and create the conditions to enlist Turkey an active ally. ${ }^{146}$ When comparing the strategic aims with the outcomes of the campaign, it is apparent that HUSKY was a success, and Patton significantly contributed to this outcome.

During the planning and execution of Operation HUSKY, Patton focused on the problem of how he would get his forces to Messina to secure the only significant strategic objective on the island of Sicily. Patton is unique in this respect because the majority of the other senior officers planning HUSKY remained distracted by the problem of successively executing the amphibious landings. The resulting lack of direction beyond the landings allowed Patton to visualize two lines of operation to Messina including a direct and indirect approach prior to the invasion. The direct approach lead directly north from his beachhead in the Gulf of Gela to the west of Mt. Etna to posture his force for a drive on Messina from the west. Patton viewed the indirect approach through Palermo as a branch plan that would provide his army with a deep water port and then place his army at a position of advantage to attack Messina from the west similar to the direct approach. The boundary dispute provided Patton the conditions required to execute his branch plan for an indirect approach to Messina through Palermo.

Patton's continued focus on Messina is indicative of his development as an operational artist in Sicily when he rearranged his tactical actions to achieve the greater strategic purpose in Sicily. The Seventh Army's seizure of Palermo served as the culmination point for Patton's

\footnotetext{
${ }^{146}$ Casablanca Conference, Papers and Minutes of Meetings.
} 
branch plan, but it was in itself a decisive point because the deep water port enabled operations to Messina. ${ }^{147}$ The lessons of Patton's professional development were evident in Sicily through his emphasis on tempo through combined arms operations and attacking the enemy in depth.

Furthermore, Patton learned how to balance operational reach with considerations of risk and opportunities to achieve decisive results at Palermo and Messina. The study of Patton's use of mission command in Sicily is interesting for the student of operational art because his level of control changed significantly during the course of the operations. Patton allowed his aggressive nature to override his judgment at Gela and during the drive on Messina with negative effects operationally and interpersonally with his subordinates. However, when Patton effectively executed mission command during the offensive to Palermo the results were excellent, and he was able to focus on tasks relevant to an army commander, such as setting conditions for subsequent phases of the operation.

Patton's rapid seizure of Palermo may have also indirectly influenced another strategic aim of Operation HUSKY to increase pressure on Italy. On 25 July Italian Dictator Benito Mussolini was overthrown, which set in motion Italy's removal from the war. A number of factors contributed to the downfall of Mussolini including: the war weariness of the Italian people, persistent Allied bombing of Rome, the deterioration of relations with Nazi Germany, and the poor performance of Italian forces in Sicily. ${ }^{148}$ Mussolini's removal occurred just three days after the Seventh Army captured Palermo. Eisenhower recognized that Patton's actions likely contributed to Mussolini's downfall when he described the influence of the loss of Palermo as "shaking the whole Italian Government so forcibly that Mussolini toppled from his position of

${ }^{147}$ William Duggan, Strategic Intuition: The Creative Spark in Human Achievement (New York: Columbia Business School Publishing, 2007), 64. Duggan made a similar argument when he discussed how Patton's knowledge of history supported his visualization to find an alternate route to Messina. Duggan referenced how Patton envisioned another route to Messina through Agrigento because that was the route used by Carthage in 406 B.C.

${ }^{148}$ D’Este, Bitter Victory, 428-440. 
power in the wake of Palermo's fall." ${ }^{149}$ Comparisons of Patton's actions in Sicily with the strategic objectives for Operation HUSKY demonstrate that he directly or indirectly contributed to every strategic aim accomplished in Sicily.

\section{CONCLUSION}

Operation HUSKY served as a crucible for Lieutenant General George S. Patton as the first American general to employ an American field army in combat during World War Two. Patton's command of the Seventh Army was exceptional, but not flawless, and it represented over thirty-four years of preparation both personally and professionally as an operational artist. Patton was a dedicated professional who devoted his life to the study of warfare. Throughout his professional military education Patton diligently prepared for each echelon of command, while he supplemented his formal education with an intensive study of military history. Patton's historical knowledge grounded his professional military education, which served as a critical component to his ability to visualize an operational environment. The skills nurtured during his professional development established the foundation of knowledge necessary for future growth as an operational artist.

Patton used his training and operational experiences in the Mexican Punitive Expedition, World War One, and the interwar maneuvers to develop an understanding for what is now called the elements of operational art. From these experiences Patton gained an appreciation for tempo, operational reach, culmination, lines of operation, basing, and risk which he experimented with throughout his early development. During Operation HUSKY Patton utilized these lessons to execute combined arms operations and employed each of these elements of operational art to achieve the decisive point of his campaign, the seizure of Palermo. While Patton's experience in CGSS provided him a rudimentary understanding of the three levels of war, army doctrine in

\footnotetext{
${ }^{149}$ Farago, Patton: Ordeal and Triumph, 314.
} 
1943 did not include operational art as it is known today. However, Patton displayed a working knowledge of how to arrange tactical actions in time and space to achieve strategic objectives.

Patton exhibited his most substantial growth as an operational artist with his ability to understand and visualize both the actions of an enemy force and his own operational approach. Prior to the invasion of Sicily, Patton envisioned the actions required to take his force to Messina despite the fact his higher headquarters never produced a unified campaign plan for Sicily. This resulted in Patton's direct and indirect approaches to Messina. Visualization enabled Patton to effectively employ his forces at the correct time and place to deter enemy actions and seize the initiative during the campaign.

Most students of Patton's operational art study his operations in France or the Battle of the Bulge. Unfortunately, the history of Patton's operational art in Sicily is overshadowed by the study of incongruent Allied strategy in the Mediterranean, or Patton's leadership flaws in Sicily. Despite significant changes in technology and the unique challenges of the current operational environment, the study of Patton's maturation as an operational artist during Operation HUSKY is relevant today. In Sicily Patton confronted a determined enemy in difficult terrain with ambiguous guidance from his multi-national higher headquarters. In these conditions he visualized an operational approach to solve a problem to successfully achieve the strategic aims of the operation. If the description above sounds similar to U.S. current operations in Afghanistan, then the relevance of studying Patton's maturation in operational art in Sicily is selfevident.

\section{RECOMMENDATIONS}

There are four recommendations derived from the study of Patton's maturation in operational art in Sicily. The first recommendation is that Army officers should emulate Patton's life-long dedication to the study of operational art. Second, Patton's execution of combined arms maneuver in restrictive terrain can inform how the Army conducts combined arms training. 
Third, the lessons Patton and the United States Army learned from conducting joint operations as a member of a multi-national headquarters provides an excellent case study for officer professional development. Fourth, the study of Patton's execution of mission command provides both positive and negative examples to follow.

Army officers should strive to emulate the dedication Patton displayed for the study of operational art. While Patton's professional military education influenced his development, his personal professional development augmented his officer education. Patton believed that professional development should be continuous, and he used reading as one of the ways to continue his education. For example, prior to World War Two, Patton read extensively on German political and military leaders anticipating that Europe would be his future operational environment. During World War Two, Patton continuously read about prior wars that occurred in the areas he fought in to help shape his understanding of tactics, terrain, and his enemies. The study of historical campaigns and the memoirs of successful military commanders supported Patton's ability to visualize operations. Patton's personal education gave him an instinctive understanding of operational art prior to its inclusion in doctrine. ${ }^{150}$

Patton's execution of combined arms operations in the restrictive terrain of Sicily provides a good example to consider as the Army returns to training for combined arms maneuver. The 2006 Hezbollah-Israeli War serves as a recent warning of what can happen when combined arms skills atrophy after years of focus on counter-insurgency operations. ${ }^{151}$

\footnotetext{
${ }^{150}$ Roger H. Nye, “Whence Patton’s Military Genius?” Parameters (Winter 1991-1992): 71. Discussed Patton's personal study of German political and military leaders based on this belief that the unbalanced results from the Treaty of Versailles at the conclusion of World War One made another war with Germany a distinct possibility. Beatrice Ayer Patton, "A Soldier's Reading," eArmor, http://www.benning.army.mil/armor/eARMOR/content/issues/2013/JUL_SEP/Patton.html (accessed 1 February 2014). Provided a list of Patton's favorite books and the books she sent to him during World War Two to assist in his understanding of his operational environment.

${ }^{151}$ Matt M. Matthews, We Were Caught Unprepared: The 2006 Hezbollah-Israeli War (Fort Leavenworth, KS: U.S. Combined Arms Center Combat Studies Institute Press, 2008), 1-3.
} 
Additionally, the terrain in Sicily required Patton's Seventh Army to rapidly transition their force structure to accommodate changing environments. In the short thirty-eight day campaign in Sicily the Seventh Army would fight in a variety of environments that included beaches, open plains, cities, and mountain environments. In a time of decreasing budgets, the study of Patton's use of combined arms teams in Sicily can augment hands-on training.

The lessons of Patton's Seventh Army in Sicily offer a good historical example of an Army force conducting joint operations within the framework of a multi-national command structure. In many respects, Sicily was a proving ground for joint operations during World War Two. Operation HUSKY revealed the numerous challenges of conducting amphibious operations followed by an extended ground campaign. The planning for Operation HUSKY illustrated the challenges of conducting multi-national operations given differences in doctrine, planning methodologies, and pre-conceived bias. Given the predominance of joint and multi-national operations in the future, the study of Operation HUSKY can benefit future military planners.

There is no shortage of resources concerning Patton's leadership. However, the study of Patton's leadership through the lens of the philosophy of mission command can provide both positive and negative examples for leaders to study. Patton provided an excellent example of mission command when he drove the operation process during the planning for Operation HUSKY. He provided clear and concise guidance, and then allowed his staff and subordinate commanders to prepare detailed plans with little interference. During the execution of operations in Sicily, Patton's execution of mission command was less consistent. The advance on Palermo displayed Patton's ability to trust his subordinates to execute his vision with little intrusion. However, during the advance on Messina Patton was overly prescriptive in his application of mission command. The lesson Patton provides students of mission command is to strive for consistency in their application of mission command. 
Appendix A: George S. Patton Biographical Timeline ${ }^{152}$

11 Nov 1885

1897-1903

1903-1904

16 Jun 1904

11 Jun 1909

12 Sep 1909

7-17 July 1912

Jul-Aug 1912

23 Sep 1913

15 Sep 1915

13 Mar 1916

23 May 1916

Feb 1917

15 May 1917

18 May 1917

10 Nov 1917

16 Dec 1917

23 Jan 1918

14 Feb 1918

3 Apr 1918

28 Apr 1918

6 Jun 1918

17 Jun-20 Aug 1918

24 Aug 1918

12-15 Sep 1918

26 Sep 1918

17 Oct 1918

2 Mar 1919

30 Jun 1920

1 Jul 1920

Jan-Jun 1923

Sep 1923- Jun 1924

Mar 1925- Apr 1928

Sep 1931- Jun 1932

1 Mar 1934

May 1935-Jun 1937

8 Feb 1938
Born, San Gabriel, CA

Student, Stephen Cutter Clark's Classical School for Boys, Pasadena, CA

Cadet, Virginia Military Academy, Lexington, VA

Entered U.S. Military Academy, West Point, NY

Graduated USMA; commissioned Second Lieutenant, $15^{\text {th }}$ Cavalry

Joined $15^{\text {th }}$ Cavalry, Fort Sheridan, IL

Participated in Modern Pentathlon, Olympic Games

Received individual instruction in fencing at Saumur, France

Reported to Mounted Service School, Fort Riley, KS

Joined $8^{\text {th }}$ Cavalry, Fort Bliss, TX

Detached from $8^{\text {th }}$ Cavalry and attached to HQ, Punitive Expedition,

Mexico

Promoted to First Lieutenant

Returned with Punitive Expedition from Mexico

Promoted to Captain

Appointed Commanding Officer, Headquarters Troop, AEF

Detailed to the Tank Service

Moved to Langres to open Light Tank Center and School

Promoted to Major

Formally assigned to command the Light Tanks, AEF (302 ${ }^{\mathrm{d}}$ Light Tank

Center)

Promoted to Lieutenant Colonel

Organized/commanded $1^{\text {st }}$ Light Tank Battalion

Organized/commanded $2^{\mathrm{d}}$ Light Tank Battalion

Student, General Staff College, Langres

Organized/Commanded $304^{\text {th }}$ Tank Brigade

St. Mihiel Offensive

Wounded near Cheppy, Meuse-Argonne Offensive

Promoted to Colonel

Sailed for U.S.

Reverted to regular grade of Captain

Promoted to Major

Student, Field Officers' Course, Fort Riley, KS

Student, Command and General Staff College, Fort Leavenworth, KS

(Honor Graduate)

Served as G-1, G-2, and G-3, Hawaiian Division

Student, Army War College, Washington, D.C. (Distinguished Graduate)

Promoted to Lieutenant Colonel

Sailed to Hawaii; G-2, Hawaiian Department

XO, Academic Division of the Cavalry School and $9^{\text {th }}$ Cavalry, Fort Riley, KS

\footnotetext{
${ }^{152}$ Martin Blumenson, ed., The Patton Papers: 1885-1940 (Boston: Houghton Mifflin Company, 1972), 965-970; Martin Blumenson, ed., The Patton Papers: 1940-1945 (Boston: Houghton Mifflin Company, 1974), 863-864.
} 
1 Jul 1938

24 Jul 1938

10 Dec 1938

26 Jul 1940

2 Oct 1940

4 Apr 1941

11 Apr 1941

Jun 1941

Aug-Sep 1941

Oct-Nov 1941

7 Dec 1941

15 Jan 1942

10 Apr 1942

8 Nov 1942

6 Mar 1943

12 Mar 1943

15 Apr 1943

10 Jul 1943

17 Aug 1943

22 Jan 1944

26 Mar 1944

6 Jun 1944

1 Aug 1944

16 Dec 1944

14 Apr 1945

9 May 1945

6 Oct 1945

9 Dec 1945

21 Dec 1945
Promoted to Colonel

$\mathrm{CO}, 5^{\text {th }}$ Cavalry, Fort Clark, TX

$\mathrm{CO}, 3^{\mathrm{d}}$ Cavalry, Fort Myer, VA

$\mathrm{CO}, 2^{\mathrm{d}}$ Armored Brigade of $2^{\mathrm{d}}$ Armored Division, Fort Benning, GA

Promoted to Brigadier General

Promoted to Major General

Assigned Acting Commanding General, $2^{\mathrm{d}}$ Armored Division

Tennessee maneuvers

Louisiana-Texas maneuvers

Carolina maneuvers

Pearl Harbor

Assigned CG, I Armored Corps

Arrived Desert Training Center

Torch landings in French North Africa

Assigned CG, II Corps in Tunisia

Promoted to Lieutenant General

Relieved from command of II Corps

Invasion of Sicily; activation of Seventh Army; assigned CG, Seventh

Army

Capture of Messina

Ordered to United Kingdom

Assigned CG, Third Army

Invasion of Normandy

Third Army becomes operational in France

German Ardennes counteroffensive

Promoted to General

End of war in Europe

Relieved of command of Third Army; assigned CG, Fifteenth Army

Car accident near Mannheim; hospitalized in Heidelberg

Death 


\title{
BIBLIOGRAPHY
}

\author{
Primary Sources
}

82d Airborne Division, 82d Airborne Division in Sicily and Italy: Report of Operations. 1945. Fort Leavenworth, KS: Combined Arms Research Library, August 2013.

Alexander of Tunis. The Alexander Memoirs 1940-1945. New York: McGraw-Hill Book Company, 1961.

Allied Force Headquarters. History of Allied Force Headquarters, Part 1: August-December 1942. Fort Leavenworth, KS: Combined Arms Research Library, August 2013.

- History of Allied Force Headquarters, Part 2 - Section 1: December 1942-December 1943. Fort Leavenworth, KS: Combined Arms Research Library, August 2013.

—. Lessons from the Sicilian Campaign. 20 November 1943. Fort Leavenworth, KS: Combined Arms Research Library, August 2013.

- Lessons of Operation Torch. 19 January 1943. Fort Leavenworth, KS: Combined Arms Research Library, August 2013.

- Order for Operation HUSKY. 1943. Fort Leavenworth, KS: Combined Arms Research Library, August 2013.

Army Service Forces, War Department. History of Planning Division, ASF. Fort Leavenworth, KS: Combined Arms Research Library, August 2013.

Bernard, Lyle W. Supply Build-Up in Amphibious Operations. Command and General Staff College School of Logistics. 5 June 1947. Fort Leavenworth, KS: Combined Arms Research Library, August 2013.

Blumenson, Martin, ed. The Patton Papers: 1885-1940. Boston: Houghton Mifflin Company, 1972.

— ed. The Patton Papers: 1940-1945. Boston: Houghton Mifflin Company, 1974.

Bradley, Omar N. A Soldier's Story. New York: Henry Holt and Company, 1951.

Combined Chiefs of Staff, Casablanca Conference (Casablanca, Morocco). Papers and Minutes of Meetings, 14-24 January 1943. Fort Leavenworth, KS: Combined Arms Resesarch Library, December 2013.

Combined Operations Headquarters. Notes on the Planning and Assault Phases of the Sicilian Campaign. October 1943. Fort Leavenworth, KS: Combined Arms Research Library, August 2013.

—. Digest of Reports on Operation “Husky”. 1 November 1943. Fort Leavenworth, KS: Combined Arms Research Library, August 2013. 
Eisenhower, Dwight D. Report on Operation TORCH. 1943. Fort Leavenworth, KS: Combined Arms Research Library, August 2013.

Headquarters, $2^{\text {nd }}$ Armored Division. Historical Record: Operations of US Second Armored Division. 5 August 1943. Fort Leavenworth, KS: Combined Arms Research Library, August 2013.

Headquarters, $45^{\text {th }}$ Infantry Division. Report of Operation of the $45^{\text {th }}$ Infantry Division in the Sicilian Campaign, 1 September 1943. Fort Leavenworth, KS: Combined Arms Research Library, August 2013.

Headquarters, Fifth Army Airborne Training Center. Report of Airborne Operations, "Husky" and "Bigot". 15 August 1943. Fort Leavenworth, KS: Combined Arms Research Library, August 2013.

Headquarters, Force 343. Annex “Item" to JOSS Attach Force Operation Plan No. 109-43. 20 June 1943. Fort Leavenworth, KS: Combined Arms Research Library, August 2013.

- Estimated Strength of Ground Forces Employed at Certain Aerodromes in Sicily. 31 May 1943. Fort Leavenworth, KS: Combined Arms Research Library, August 2013.

—. G-2 Estimate of the Enemy Situation \#2. 5 May 1943. Fort Leavenworth, KS: Combined Arms Research Library, August 2013.

Headquarters, Ninth Infantry Division. Reports on Operations, $9^{\text {th }}$ Infantry Division: Southern Tunisia, Northern Tunisia, and Sicily. 5 October 1943. Fort Leavenworth, KS: Combined Arms Research Library, August 2013.

Headquarters, Royal Air Force. RAF Mediterranean Review, No. 4. July-September 1943. Fort Leavenworth, KS: Combined Arms Research Library, August 2013.

Headquarters, Seventh Army. G-2 Estimate of Enemy Situation. 1 August 1943. Fort Leavenworth, KS: Combined Arms Research Library, August 2013.

Headquarters, Third Infantry Division. Report of Operation. 10 September 1943. Fort Leavenworth, KS: Combined Arms Research Library, August 2013.

Montgomery, Bernard. The Memoirs of Field-Marshal Montgomery. Cleveland, OH: The World Publishing Company, 1958.

Moore, R. E. "Reconnaissance in Force at Agrigento, Sicily, 12-16 July 1943 (3 ${ }^{\text {rd }}$ Infantry Division)." Fort Leavenworth, KS: Command and Staff College, 1947.

Patton, George S. War As I Knew It. 1947. Reprint, New York: Pyramid, 1966.

Province, Charles M., ed. Military Essays and Articles. San Diego: The George S. Patton, Jr. Historical Society, 2002. 
Staff of the Seventh Army. Report of the Operations of the US Seventh Army in the Sicilian Campaign. 1943. Fort Leavenworth, KS: Combined Arms Research Library, August 2013.

Truscott, Jr., Lucian K. Command Missions: A Personal Story. New York: E.P. Dutton and Company, Inc., 1954.

United States War Department. Lessons from Operation “Torch”. 24 January 1943. Fort Leavenworth, KS: Combined Arms Research Library, August 2013.

$$
\text { Joint and Army Doctrine }
$$

United States War Department. Field Service Regulations United States Army 1923. Washington, DC: Government Printing Office, 1923.

. FM 17: Armored Force Field Manual: Employment of Armored Units. Washington, DC: Government Printing Office, 1942.

- FM 17-10: Armored Force Field Manual: Tactics and Technique. Washington, DC: Government Printing Office, 1942.

-. FM 100-5: Staff officers' Field Manual and Staff Combat Orders. Washington, DC: Government Printing Office, 1940.

- FM 100-5: Field Service Regulations: Operations. Washington, DC: Department of the Army, May 1941.

- FM 100-15: Field Service Regulations: Larger Units. Washington, DC: Government Printing Office, 1942.

Headquarters, Department of the Army. FM 100-5, Operations, Washington, DC: Government Printing Office, 1982.

-. FM 100-5: Operations, Washington, DC: Government Printing Office, 1986.

ADRP 3-0: Unified Land Operations. Washington, DC: Government Printing Office, May 2012.

- ADRP 5-0: The Operations Process. Washington, DC: Government Printing Office, May 2012.

- ADRP 6-0: Mission Command. Washington, DC: Government Printing Office, May 2012.

Headquarters, Joint Staff. Joint Publication 3-0, Joint Operations. Washington, DC: Government Printing Office, August 2011.

—. Joint Publication 5-0, Joint Operational Planning. Washington, DC: Government Printing Office, August 2011. 


\section{Secondary Sources}

Astor, Gerald. Terrible Terry Allen: Combat General of World War II - The Life of an American Soldier. New York: Ballantine Books, 2003.

Atkinson, Rick. An Army at Dawn: The War in North Africa, 1942-1943. New York: Henry Holt and Company, 2002.

- The Day of Battle: The War in Sicily and Italy, 1943-1944. New York: Henry Holt and Company, 2007.

- The Guns at Last Light: The War in Western Europe, 1944-1945. New York: Henry Holt and Company, 2013.

Birtle, Andrew J. Sicily. Washington, DC: Center for Military History, United States Army, 1993.

Blackwell, Ian. Battle for Sicily: Stepping Stone to Victory. South Yorkshire, Pen and Sword Books, 2008.

Blumenson, Martin. Patton: The Man Behind the Legend, 1885-1945. New York: William Morrow, 1985.

- Sicily, Whose Victory? New York: Ballantine Books, 1968.

Brighton, Terry. Patton, Montgomery, Rommel: Masters of War: A Story of the Three Greatest Generals of the Greatest War. New York: Three Rivers Press, 2008.

Cameron, Robert S. Mobility, Shock, and Firepower: The Emergence of the U.S. Army's Armor Branch 1917-1945. Washington, DC: Center of Military History, 2008.

Center of Military History. Germany and Italy: Mediterranean and Adjacent Areas. Washington, DC: Center of Military History, United States Army, 1988.

Clausewitz, Carl Von. On War. Princeton, NJ: Princeton University Press, 1976.

Coffman, Edward M. The War To End All War: The American Military Experience in World War I. Lexington, KY: The University Press of Kentucky, 1998.

Cole, Hugh M. The Ardennes: Battle of the Bulge. Washington, DC: Center of Military History, United States Army, 1993.

D'Este, Carlo. Bitter Victory: The Battle for Sicily, 1943. New York: E.P. Dutton, 1988.

_. Eisenhower: A Soldier's Life. New York: Henry Holt and Co., 2002.

—. Patton: A Genius for War. New York: Harper Perennial, 1996.

Duggan, William. Strategic Intuition: The Creative Spark in Human Achievement. New York: Columbia Business School Publishing, 2007. 
Dupuy, R. Ernest and Trevor N. Dupuy. The Harper Encyclopedia of Military History, $4^{\text {th }}$ ed. New York: HarperCollins Publishers, 1993.

Essame, H. Patton as Military Commander. London, Da Capo Press, 1974.

Farago, Ladislas. Patton, Ordeal and Triumph, New York: Dell Books, 1970.

Fiebeger, G.J. Elements of Strategy. New York: United States Military Academy Press, 1906.

Ford, Ken. Assault on Sicily: Monty and Patton at War. United Kingdom, Sutton Publishing, 2007.

Garland, Albert N. and Howard M. Smyth. United States Army in World War II: The Mediterranean Theater of Operations, Sicily and the Surrender of Italy. Washington, D.C.: Office of the Chief of Military History, Department of the Army, 1965.

Hays, Robert. Patton's Oracle: Gen. Oscar Koch, as I Knew Him. Savoy, IL: Lucidus Books, 2013.

Hirshson, Stanley P. General Patton: A Soldier's Life. New York: Harper Perennial, 2002.

Howe, George F. Northwest Africa: Seizing the Initiative in the West. Washington, DC: Center of Military History, United States Army, 1993.

Jeffers, H. Paul. Command of Honor: General Lucian Truscott's Path to Victory in World War II. New York: Penguin Group, 2008.

Jomini, Antoine De. The Art of War. South Yorkshire, UK: Greenhill Books, 2006.

Keegan, John. The Second World War. New York: Penguin Books, 1989.

Koch, Oscar W. and Robert Hays. G-2: Intelligence for Patton. Atglen, PA: Schiffer Publishing, 1999.

Lande, D.A. I was with Patton: First-Person Accounts of WWII In George Patton S. Patton's Command. St. Paul, MN: MBI Publishing Company, 2002.

MacDonald, Charles D. A Time for Trumpets: The Untold Story of the Battle of the Bulge. New York: Bantam Books, 1984.

Matheny, Michael R. Carrying the War to the Enemy: American Operational Art to 1945. Norman, OK: University of Oklahoma Press, 2011.

Matthews, Matt M. We Were Caught Unprepared: The 2006 Hezbollah-Israeli War. Fort Leavenworth, KS: U.S. Combined Arms Center Combat Studies Institute Press, 2008.

Millett, Allan R. and Peter Maslowski. For the Common Defense: A Military History of the United States of America. New York: The Free Press, 1984. 
Mitchum, Samuel W. Jr. and Stephen Von Stauffenberg. The Battle of Sicily. New York: Orion Books, 1991.

Morison, Samuel Eliot. History of United States Naval Operations in World War II, Vol. IX: Sicily-Salerno-Anzio January 1943 - June 1944. Boston: Little, Brown and Company, 1954.

Naylor, William. Principles of Strategy. Fort Leavenworth, KS: The General Service School's Press, 1921.

Nye, Roger H. The Patton Mind: The Professional Development of an Extraordinary Leader. New York: Avery Publishing Group, 1993.

Pack, S.W.C. Operation "Husky” The Allied Invasion of Sicily. New York: Hippocrene Books, Inc., 1977.

Pond, Hugh. Sicily. London: William Kimber \& Co., 1962

Schifferle, Peter J. America's School for War: Fort Leavenworth, Officer Education, and Victory in World War II. Lawrence, KS: University Press of Kansas, 2010.

Sixsmith, E.K.G. Eisenhower as Miliary Commander. New York: Stein and Day Publishers, 1972.

Winton, Harold R. Corps Commanders of the Bulge: Six American Generals and Victory in the Ardennes. Lawrence, KS: University Press of Kansas, 2007.

Journals

Dougherty, Kevin J. "Invading Sicily: A Tale of Branches and Sequels.” JFQ 31 (Summer 2002): 108-113.

Dougherty, Kevin. "Our MI Heritage: Oscar Koch: An Unsung Hero Behind Patton's Victories.” Military Intelligence Professional Bulletin 28, no. 2 (April-June 2002): 64-66.

Nye, Roger H. “Whence Patton's Military Genius?” Parameters (Winter 1991-1992): 60-73.

Patton, Beatrice Ayer. “A Soldier's Reading." eArmor, http://www.benning.army.mil/armor/ eARMOR/content/issues/2013/JUL_SEP/Patton.html (accessed 1 February 2014).

Monographs and Theses

Barnhart, Barton V. "The Great Escape: An Analysis of Allied Actions Leading to the Axis Evacuation of Sicily in World War II." Thesis, United States Army Command and General Staff College, 2003.

Claflin, Robert C. "The Operational Art as Practiced by General George Patton, Jr. During the Battle of the Bulge.” Thesis, Naval War College, 1994. 
Colbert, Richard, Joseph Bowab, Zale Cook, Dell Dailey, Jerry DeMoney, Abbass Fouad, Martha James, Warrenn Mills, Dennis Morin, David Wheeler, and Timothy Wilcox.

"OPERATION JOSS: Amphibious, Deliberate Assault, Offensive." Combat Studies Institute, 1984.

Cote, Stephen R. "Operation HUSKY: A Critical Analysis.” Thesis, Naval War College, 2001.

Duggan, William. “Coup D’Oeil: Strategic Intuition in Army Planning." Thesis, United States Army War College, 2005.

Flowers, Jack D. "Patton, Third Army and Operational Maneuver." Monograph, School of Advanced Military Studies, 1998.

Higgins, George A. "The Operational Tenets of Generals Heinz Guderian and George S. Patton, Jr.” Monograph, School of Advanced Military Studies, 1985.

Jordan, Stephen T. "Operational Art: Practical Utility of Defunct Doctrinal Concept." Monograph, School of Advanced Military Studies, 1991.

Kaune, Patrick N. "General Troy H. Middleton: Steadfast in Command.” Monograph, School of Advanced Military Studies, 2011.

Kurz, Joseph. "General Matthew B. Ridgway: A Commander's Maturation of Operational Art." Monograph, School of Advanced Military Studies, 2011.

Nowowiejski, Dean A. "Concepts of Information Warfare in Practice: General George S. Patton and the Third Army Information Service August-December 1944." Monograph, School of Advanced Military Studies, 1995.

Prescott, James E. "What Operational Level of War Lesson Can Be Learned From the Allied Invasion of Sicily?" Thesis, Naval War College, 1994.

Read, Steven N. "Planning for the Unplannable: Branches, Sequels, and Reserves." Monograph, School of Advanced Military Studies, 1990.

Sanderson, Jeffrey R. "General George S. Patton, Jr.: Master of Operational Battle Command. What Lasting Battle Command Lessons Can We Learn From Him?" Monograph, School of Advanced Military Studies, 1997.

Sklenka, Stephen D. "General George S. Patton: Operational Leadership Personified.” Thesis, Naval War College, 2002.

Swanson, Jon M. "Operation Husky, The Campaign in Sicily: A Case Study.” Thesis, United States Army War College, 1992. 